University of Michigan Law School

University of Michigan Law School Scholarship Repository

Articles

Faculty Scholarship

2014

\title{
The Influence of Arbitrator Background and Representation on Arbitration Outcomes
}

\author{
Adam C. Pritchard \\ University of Michigan Law School, acplaw@umich.edu \\ Stephen J. Choi \\ New York University \\ Jill E. Fisch \\ University of Pennsylvania
}

Available at: https://repository.law.umich.edu/articles/1562

Follow this and additional works at: https://repository.law.umich.edu/articles

Part of the Dispute Resolution and Arbitration Commons, Litigation Commons, and the Securities Law Commons

\section{Recommended Citation}

Pritchard, Adam C. "The Influence of Arbitrator Background and Representation on Arbitration Outcomes." S. J. Choi and J. E. Fisch, co-authors. Va. L. \& Bus. Rev. 9, no. 1 (2014): 43-90.

This Article is brought to you for free and open access by the Faculty Scholarship at University of Michigan Law School Scholarship Repository. It has been accepted for inclusion in Articles by an authorized administrator of University of Michigan Law School Scholarship Repository. For more information, please contact mlaw.repository@umich.edu. 


\section{VIRGINIA LAW \& BUSINESS REVIEW}

\begin{tabular}{cc}
\hline \hline VOLUME 9 & FALL 2014 \\
\hline \hline \\
THE INFLUENCE OF ARBITRATOR BACKGROUND \\
AND REPRESENTATION ON ARBITRATION \\
OUTCOMES
\end{tabular}

Stephen J. Choi, Jill E. Fisch, and A.C. Pritchard ${ }^{\dagger}$

We study the role of arbitrator background in securities arbitration. We find that several aspects of arbitrator background are correlated with arbitration outcomes. Specifically, industry experience, prior experience as a regulator, and status as a professional or retired arbitrator are correlated with statistically significant differences in arbitration anvards. The impact of these characteristics is affected by whether the arbitrator in question serves as the panel chair and by whether the parties to the arbitration are represented by counsel.

Our findings offer some preliminary insights into the debate over possible arbitrator bias. On the one hand, they suggest that the party selection process is relatively effective in screening for bias. The Financial Industry Regulatory Association has imposed increasingly more rigorous qualification requirements, specifically with respect to the independence of public arbitrators, but our study suggests that these requirements are unlikely to affect outcomes in most cases. On the other band, party selection appears to be most effective when the parties are represented by counsel. Our findings bighlight the importance of legal representation in the arbitration process.

\footnotetext{
STEPHEN J. CHOI is the Murray and Kathleen Bring Professor of Law, New York University, JILL E. FISCH is the Perry Golkin Professor of Law, University of Pennsylvania, and A.C. PRITCHARD is the Frances and George Skestos Professor of Law, University of Michigan. The authors thank numerous individuals who assisted us in collecting the background information on arbitrators for our analysis. We are also grateful to the Searle Civil Justice Institute for financial support of this project. Finally, we are grateful to participants at the Arbittation Research Roundtable sponsored by the Searle Civil Justice Institute, the Conference on Empirical Legal Studies, the annual meeting of the American Law \& Economics Association, the University of Toronto Law \& Economics Workshop and the Advanced Business Law Seminar at Fordham Law School for helpful comments on earlier dtafts of the article.
}

Copyright (C 2014 Virginia Law \& Business Review Association 


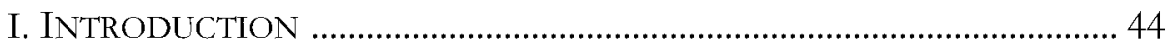

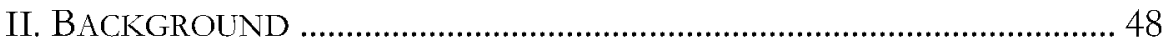

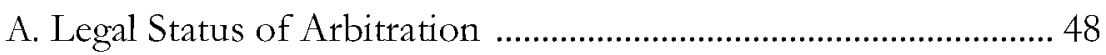

B. FINRA Procedures ............................................................................ 52

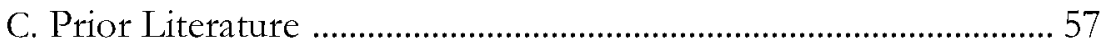

D. Party Selection and the Judicial Decision-making Literature ... 58

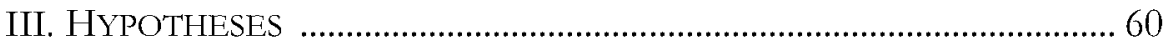

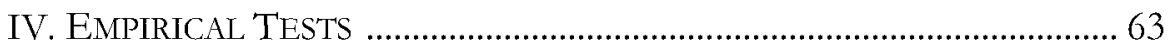

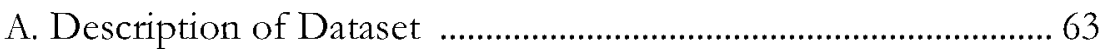

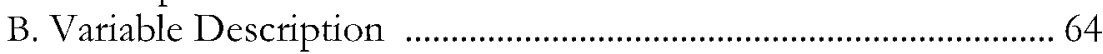

C. Industry Experience ................................................................... 70

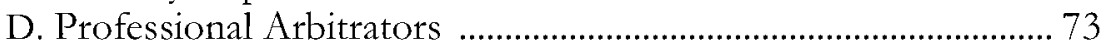

E. Retired Arbitrators ....................................................................... 75

F. Regulatory Experience ................................................................ 78

G. Compliance Officers ................................................................... 82

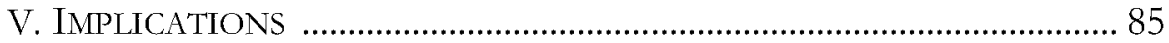

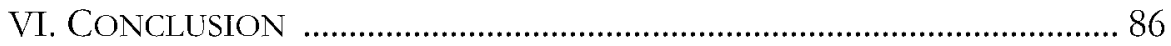

APPENDIX: VARIABLE DEFINITION ........................................................ 88

\section{INTRODUCTION}

NANDATORY arbitration has been the norm in the securities industry 1 for broker-customer disputes since the late 1980s when the Supreme Court upheld mandatory arbitration provisions in broker-customer agreements. ${ }^{1}$ Mandatory arbitration has been a standard term in such agreements ever since. Even where arbitration is not mandated by contract, the Financial Industry Regulatory Association ("FINRA"), an industry selfregulatory organization, ${ }^{2}$ requires brokers to arbitrate all broker-customer

Rodriguez de Quijas v. Shearson/Am. Express, Inc., 490 U.S. 477 (1989); Shearson/Am. Express v. McMahon, 482 U.S. 220 (1987).

2 FINRA succeeded the National Association of Securities Dealers and the enforcement divisions of the New York Stock Exchange as the self-regulatory organization for the securities industry. FINRA handles arbitration of both broker-customer disputes and disputes between FINRA member firms and their employees, which are subject to a 
disputes if the customer so requests. ${ }^{3}$ As a result, the overwhelming majority of broker-customer disputes, even those involving substantial sums, are resolved through arbitration. ${ }^{4}$

The FINRA arbitration process has been the subject of ongoing controversy, as critics have debated the fairness of the arbitration process for customers. ${ }^{5}$ This debate is impeded by the limited transparency of arbitration cases. Although FINRA releases the written decisions issued by arbitration panels, it does not disclose the details of the claims filed or background information on the arbitrators who issue these decisions. ${ }^{6}$ Moreover, under FINRA's arbitration rules, arbitrators only need to disclose minimal information in their awards. ${ }^{7}$ In particular, FINRA rules do not require the arbitrators to explain the reasons for their decision unless all the parties jointly request such an explanation. ${ }^{8}$

Studying arbitration is further complicated by a distinctive party selection regime. FINRA arbitration panels combine industry members with neutral or public arbitrators, who are private individuals, not employees of FINRA. ${ }^{9}$ Thus, arbitrators are recruited both from within and outside the securities industry. From a standing pool of around 6,000 arbitrators, FINRA generates

different set of arbitration procedures. See FINRA Code of Arbitration Procedure, http://www.finra.org/ArbitrationAndMediation/Arbitration/Rules/CodeofArbitrationPr ocedure/ (last visited Sept. 10, 2013) (stating that "The Code of Arbitration Procedure for Industry Disputes (Industry Code) governs arbitrations between or among industry parties only"). This article only analyzes arbitration that results from disputes between brokers and their customers.

3 FINRA Code of Arbitration Procedure for Customer Disputes ("FINRA Code") $\$ 12200$ (2008), available

http://finra.complinet.com/en/display/display_main.html?rbid=2403\&element_id=410.

4 See, e.g., STMicroelectronics, N.V. v. Credit Suisse Sec. (USA) LLC, 648 F.3d 68 (2d Cir. 2011) (upholding trial court's confirmation of $\$ 400$ million arbitration award).

5 See, e.g., Stephen J. Choi, Jill E. Fisch \& A. C. Pritchard, Attomeys as Arbitrators, 39 J. LEGAL STUD. 109, 110-11 (2010) (summarizing criticisms of FINRA's arbitration process).

6 By contrast, judges' backgrounds are generally a matter of public record. Thus our study, which is in the vein of a substantial body of legal scholarship about judicial decisionmaking, see, e.g., Diane P. Wood, When to Hold, When to Fold, and When to Reshuffle: The Ant of Decisionmaking on a Multi-Member Court, 100 CALIF. L. REv. 1445 (2012), is distinctive in that we have collected data about the arbitrators making the decisions in our sample.

7 See FINRA Code of Arbitration Procedure for Customer Disputes ("FINRA Code") $\$$ 12904(e) (2008), available at http://finra.complinet.com/en/display/display_main.html?tbid=2403\&element_id $=4192$ (designating information required in an arbitration award).

$8 \quad$ See id. $\$ 12904(\mathrm{~g})$.

$9 \quad$ See infra notes 43-75 and accompanying text (describing FINRA's party selection system). 
a list of potential arbitrators for each case, and the parties then select their arbitrators from this list. ${ }^{10}$ This party selection procedure and the qualifications of the arbitrators, particularly the issue of who constitutes a public arbitrator, have been the subject of ongoing debate and reform, as FINRA has attempted to respond to criticism about the fairness of the arbitration process. ${ }^{11}$

In particular, FINRA's reforms to the definition of "independent arbitrator" suggest concern about the role arbitrator background may play in the outcome of arbitration cases. ${ }^{12}$ The party selection process, however, may mitigate these effects as parties reject arbitrators who may be unsympathetic to their claims. ${ }^{13}$ The intersection of these effects raises the question addressed by our study: Does the selection of arbitrators have an effect on arbitration outcomes? And are there other mechanisms, such as legal representation, that may help mitigate any biases resulting from specific arbitrator backgrounds, particularly ties to the securities industry?

Apart from its effect on securities arbitrations-important in its own right $^{14}$ — understanding the significance of arbitrator characteristics is important because of the increasing use of arbitration as a potential alternative to other forms of investor litigation. ${ }^{15}$ Public corporations may adopt bylaws requiring shareholders to arbitrate disputes with the company,

$10 \quad$ Id.

11 See, e.g., Self-Regulatory Organizations; National Association of Securities Dealers, Inc. (n/k/a Financial Industry Regulatory Authority, Inc.); Order Approving Proposed Rule Change to Amend the Definition of Public Arbitrator, Securities Exchange Act Release No. 57492 (March 13, 2008), 2-5, available at www.sec.gov/rules/sro/nasd/2008/3457492.pdf (describing various changes to the definition of a public arbitrator designed "to ensure the integrity and neutrality of the forum's arbitrator

Roster.")

12 Id.

13 Cf. Jiro E. Kondo, Self-Regulation and Enforcement in Financial Markets: Evidence from Investor-Broker Disputes at the NASD (Nov. 20, 2006) (unpublished manuscript) (on file with author) (examining effect of arbitrator background on their selection).

14 Customers file an average of more than 6,000 arbitration claims per year. FINRA Dispute REsOlution STATISTiCs, http://www.finra.org/ArbitrationAndMediation/FINRADisputeResolution/AdditionalR esources/Statistics/index.htm (last visited Sep. 9, 2014).

15 See Hal Scott \& Leslie N. Silverman, Stockbolder Adoption of Mandatory Individual Arbitration for Stockbolder Disputes, 36 Harv. J.L. \& Pub. POL'y 1187 (2013). See also CompuCredit Corp. v. Greenwood, 132 S. Ct. 665, 672 (2012) (observing that "the early 1990's saw the increased use of arbitration clauses in consumer contracts generally, and in financial services contracts in particular"). 
its officers, and directors. ${ }^{16}$ This prospect has grown increasingly likely in light of the U.S. Supreme Court's ever-growing receptivity to arbitration clauses. ${ }^{17}$ Understanding the effect of arbitrator characteristics on case outcomes sheds light on the attractiveness of arbitration as an alternative to litigation.

Critical to the policy debate over arbitration provisions is the question of whether arbitration treats small claimants-consumers and customers-fairly. The literature evaluating the relative merits of arbitration versus litigation is extensive. Several empirical studies have examined arbitration in the consumer and employment context, but their conclusions are mixed.18 In addition, an analysis of arbitrator characteristics fits within a growing scholarly literature exploring judicial decision-making. Empirical research has demonstrated that the personal characteristics of judges affect their behavior on the bench. ${ }^{19}$ Do arbitrators exhibit similar partisan or biased behavior? That question is sharpened by the opaqueness of the arbitration process and its insulation from appellate review. These factors combine to make arbitration less closely tethered to the so-called "rule of law." Put less cynically, to what extent does the individual arbitrator's life experience affect his or her awards?

To explore the effect of arbitrator background on arbitration outcomes, we analyze a dataset of randomly selected arbitration awards from 1998 to 2000. During that period, the limitations on who qualified to serve as a public arbitrator were less restrictive than today. ${ }^{20}$ We hand collect data on the background characteristics of the arbitrators who issued the awards in our

16 See, e.g., Corvex Mgmt. LP v. CommonWealth REIT, No. 24-C-13-001111, 2013 WL 1915769 (Md. Cir. Ct. May 8, 2013) (upholding arbitration clause for publicly-traded REIT). In its public offering filings in 2012, the Carlyle Group initially indicated that it intended to include a provision requiring shareholders to use arbitration rather than litigation. The provision was dropped after opposition from investors and the SEC. See Kevin Roose, Carlyle Drops Arbitration Clause From I.P.O. Plans, N.Y. Times (Feb. 3, 2012), http://dealbook.nytimes.com/2012/02/03/carlyle-drops-arbittation-clause-from-i-p-oplans/.

17 In its most recent decision, Am. Express Co. v. Italian Colors Rest., 133 S. Ct. 2304 (2013), the Court held that arbitration clauses should be enforced even if they make it impossible for parties to actually vindicate their rights.

18 See Choi et al., supra note 5, at 119 (summarizing the literature).

19 See, e.g., James J. Brudney, et al., Judicial Hostility Toward Labor Unions? Applying the Social Background Model to a Celebrated Concern, 60 OHIO ST. L.J. 1675 (1999); Cass R. Sunstein, David Schkade \& Lisa M. Ellman, Ideological Voting on Federal Courts of Appeals: $A$ Preliminary Investigation, 90 VA. L. REV. 301 (2004).

20 See, e.g., SEC Release, supra note 11 (describing some of the limitations imposed by rule changes subsequent to 2000 ). 
sample, focusing on whether those arbitrators: (1) had prior securities experience, (2) served as professional arbitrators, (3) were retired, or (4) had previously served either as a regulator or a compliance officer. We explore whether the presence of arbitrators with these characteristics on a panel affects the size of the arbitration award. We also explore whether the presence of counsel affects the impact of these background characteristics.

Our findings are as follows: With respect to securities experience and industry ties, the characteristics that have been the primary focus of FINRA's ongoing regulatory changes, we find that securities experience matters- that is, arbitrators with connections to the industry issue lower awards. That effect appears to be limited, however, to cases in which the claimant is not represented by counsel. With respect to professional and retired arbitrators, whom some commentators have observed might display a more subtle form of bias due to their desire to be selected in future cases, we find some evidence that these arbitrators tend to issue lower awards. Further, we find that this effect is not mitigated by legal representation. Finally, we find some evidence that public arbitrators with regulatory experience are inclined toward larger awards if they do not serve as the panel chair. This effect is mitigated, but not eliminated, by the presence of an attorney for the respondent. We also find some evidence that there is a difference in awards if the industry arbitrator has experience as a compliance officer, depending on whether the claimant is represented by counsel. Our results provide preliminary evidence that FINRA's focus on arbitrator characteristics was valuable in that such characteristics do have the capacity to affect case outcomes.

We proceed as follows: Part 2 sets out the background of the FINRA customer arbitration procedure; Part 3 sets forth our hypotheses; Part 4 describes our sample and variables, and reports the results of our empirical tests; and Part 5 discusses the implications of our results.

\section{BACKGROUND}

\section{A. Legal Status of Arbitration}

Since the late 1980s, the Supreme Court has taken a consistent position endorsing arbitration as an alternative system of dispute resolution, reading congressional adoption of the Federal Arbitration Act ("FAA") as reflecting a "'federal policy favoring arbitration."'21 Specifically, the Court held in 1987 in

21 Shearson/Am. Express v. McMahon, 482 U.S. 220, 226 (1987) (quoting Moses H. Cone Memorial Hosp. v. Mercury Constr. Corp., 460 U.S. 1, 24 (1983)). 
Shearson/American Express v. McMabon that arbitral forums were fully capable of resolving securities fraud disputes. ${ }^{22}$ Two years later in Rodrigues de Quijas $v$. Shearson/American Express, Inc., the Supreme Court explicitly overruled its prior decision in Wilko v. Swan and held that pre-dispute arbitration agreements were valid for claims arising under the Securities Act of 1933.23 Subsequently, the Supreme Court has repeatedly emphasized its approval of arbitration as offering "lower costs, greater efficiency and speed, and the ability to choose expert adjudicators to resolve specialized disputes" relative to litigation. ${ }^{24}$ The Court has held that arbitration can be used to resolve claims that would otherwise be brought as part of a class action. ${ }^{25}$ Most recently, the Supreme Court held that arbitration agreements containing class action waivers must be enforced by the courts even if the cost of pursuing an individual claim would be prohibitively expensive. ${ }^{26}$

The Supreme Court's expansive reading of the FAA has resulted in a deferential judicial review of arbitration awards. Under the Court's interpretation of the FAA, courts are not permitted to overturn arbitration awards on the basis that the arbitrators misinterpreted or misapplied applicable law. ${ }^{27}$ Although in the past courts granted motions to vacate arbitration awards in which the arbitrators were found to have manifestly disregarded the law, 28 the Supreme Court's most recent interpretation of "manifest disregard" suggests that this language may just be a "judicial gloss"

22 Id. at 242. The Court based its holding, in part, on the fact that "the Commission has broad authority to oversee and to regulate the rules adopted by the SROs relating to customer disputes, including the power to mandate the adoption of any rules it deems necessary to ensure that arbitration procedures adequately protect statutory rights." Id. at 233-34.

23 Rodriguez de Quijas v. Shearson/Am. Express, Inc., 490 U.S. 477, 485 (1989).

24 Stolt-Nielsen S.A. v. AnimalFeeds Int'l Corp., 559 U.S. 662, 685 (2010).

25 AT\&T Mobility LLC v. Concepcion, 131 S. Ct. 1740 (2011).

26 Am. Express Co. v. Italian Colors Rest., 133 S. Ct. 2304 (2013). The extent to which brokers may require their customers to waive their rights to participate in class action litigation, since FINRA arbitrators do not have the power to adjudicate disputes on a class basis, was recently the subject of litigation between FINRA and Charles Schwab. See Tess Stynes \& Caitlin Nish, Finra Panel: Regulator Can't Block Scbwab Arbitration Agreement, WALL ST. J. (Feb. 22, 2013), http://online.wsi.com/article/SB10001424127887323549204578319933909503430.html (describing preliminary decision by FINRA hearing panel in favor of Schwab). FINRA's Board of Governors reversed the hearing panel decision upholding the class action waiver. William Alden, Schwab Agress to Drop Effort to Prevent Class-Action Lawsuits, N.Y. Times, April 24, 2014.

27 See, e.g., United Paperworkers Int'l Union v. Misco, Inc., 484 U.S. 29, 38 (1987).

28 See, e.g., McCarthy v. Citigroup Global Mkts., Inc., 463 F.3d 87, 91 (1st Cir. 2006) (citations omitted). 
on the explicit grounds for vacatur set out in the FAA. ${ }^{29}$ Lower courts have read this Supreme Court precedent as holding that the statutory grounds for vacating or modifying an arbitration award are exclusive. 30

These legal standards limit the extent to which courts can review arbitration procedures for bias. Under section 10(a) of the FAA, a court can vacate a decision if it finds "evident partiality" or "other misbehavior" of the arbitrators. ${ }^{31}$ Courts have interpreted evident partiality as involving a relationship with an arbitrator, a lawyer, or a party ${ }^{32}$ rather than an arbitrator's predisposition or general views about the law or the industry. ${ }^{33}$ Relevant here, courts have rejected the argument that an arbitrator's position or experience within the industry is sufficient to meet the legal standard of bias, ${ }^{34}$ even if that position might present the appearance of bias..$^{35}$ Moreover, to the extent that the arbitrators disclose any potential biases or conflicts, or relationships that create the potential for bias, courts have held such disclosure insulates the award from subsequent challenge because a party can respond to the

29 The primary such authority is contained in FAA $\$ 10(a)(3)$, which allows courts to vacate arbitration awards only "where the arbitrators were guilty of misconduct in refusing to postpone the hearing, upon sufficient cause shown, or in refusing to hear evidence pertinent and material to the

controversy; or of any other misbehavior by which the rights arbitral proceedings is itself desirable, reducing the cost and increasing the speed of dispute resolution." See StoltNielsen, 559 U.S. at 672, n. 3 ("We do not decide whether 'manifest disregard' survives our decision in Hall Street Associates, LLC. v. Mattel, Inc, 552 U.S. 576, 585 (2008), as an independent ground for review or as a judicial gloss on the enumerated grounds for vacatur set forth at 9 U.S.C. $\$ 10 . "$ ) (internal quotation marks omitted).

30 See, e.g., Frazier v. CitiFinancial Corp., 604 F.3d 1313, 1323-24 (11th Cir. 2010) (holding that the common law standards for vacatur are, therefore, no longer valid); Citigroup Global Mkts., Inc. v. Bacon, 562 F.3d 349, 358 (5th Cir. 2009).

31 STMicroelectronics, N.V. v. Credit Suisse Sec. (USA) LLC, 648 F.3d 68, 74 (2d Cir. 2011).

32 Id. at 74. See also Positive Software Solutions, Inc. v. New Century Mortg. Corp., 476 F.3d 278 (5th Cir. 2007) (analyzing the nature of relationships that might require vacatur of arbitration award for partiality).

33 See, e.g., Republican Party of Minn. v. White, 536 U.S. 765, 777 (2002) ("A judge's lack of predisposition regarding the relevant legal issues in a case has never been thought a necessary component of equal justice.").

34 See, e.g., Positive Software Solutions, Inc., 476 F.3d 278, 286 (noting that "the best lawyers and professionals ... normally have the longest lists of potential connections to disclose").

35 STMictoelectronics, 648 F.3d at 74-77. See also Owen-Williams v. BB\&T Inv. Servs., 717 F. Supp.2d 1, 19 (D.D.C. 2010) ("It is well established that a mere appearance of bias is insufficient to demonstrate evident partiality." (quoting Williams Fund Private Equity Grp., Inc. v. Engel, 519 F.Supp.2d 100, 104 (D.D.C. 2007))) 
disclosure by striking the arbitrator or seeking his or her removal from the panel. ${ }^{36}$

The Supreme Court's enthusiastic endorsement of arbitration suggests the possible expansion of arbitration as a mechanism for the resolution of a broader range of investor disputes. In 2012, the Carlyle Group filed a registration statement with the Securities and Exchange Commission ("SEC") in connection with its initial public offering that proposed provisions requiring investors to resolve any disputes through individual arbitration rather than litigation. Carlyle's filing generated a heated critical response, with critics arguing that Carlyle's actions were designed to strip shareholders of important rights. ${ }^{37}$ Carlyle subsequently withdrew the arbitration provision, but commentators continue to speculate that corporations may adopt bylaw provisions requiring arbitration of shareholder disputes. ${ }^{38}$ More recently, a Maryland state court upheld an arbitration bylaw in a real estate business trust, holding that the shareholders challenging the bylaw had implicitly assented to its terms. ${ }^{39}$

This groundswell favoring arbitration has met some resistance. Congress has considered statutory changes to restrict pre-dispute arbitration clauses. Concern about the fairness of arbitration to small claimants has led members of Congress to introduce proposed legislation limiting compelled arbitration of such disputes. ${ }^{40}$ The Dodd-Frank Act of 2010 authorizes (but does not require) the SEC to limit or prohibit agreements requiring customers of any broker or dealer to arbitrate future disputes arising under federal securities laws. ${ }^{41}$ Some commentators have warned that limiting customer arbitration

36 See, e.g., Cortina v. Citigroup Global Mkts., Inc., No. 10cv2423-L(RBB), 2011 U.S. Dist. LEXIS 92954, at *17-18 (S.D. Cal. Aug. 19, 2011) ("Because the arbitrator disclosed prior to the hearing the facts Petitioner contends give the impression of bias, his request to vacate the award based on non-disclosure is denied.").

37 See, e.g., Miles Weiss, Carlyle Curbing Shareholder Rights Irritates Lawmakers Who See Precedent, BLOOMBERG (Jan. 26, 2012, 12:01 AM), http://www.bloomberg.com/news/2012-0126/carlyle-lawsuit-ban-deplored-by-lawmakers-may-entice-followers.html (quoting U.S. Senator Richard Blumenthal as stating that "The SEC should reject this effort to circumvent shareholder rights because it will be an extraordinary and enduring precedent.").

38 See, e.g., Kevin M. LaCroix, More About Arbitration Clauses in Corporation By-Laws, THE D\&O DIARY (July 11, 2013), http://www.dandodiary.com/2013/07/articles/director-andofficer-liability/more-about-arbitration-clauses-in-corporate-by-laws/.

39 Corvex Mgmt. LP v. CommonWealth REIT, No. 24-C-13-001111, 2013 WL 1915769 (Md. Cir. Ct. May 8, 2013).

40 See, e.g., Arbittation Fairness Act of 2013, H.R. 1844, 113th Cong. \$402(a) (2013).

41 Dodd-Frank Wall Street Reform and Consumer Protection Act, H.R. 4173, 111 th Cong. $\$ 921$ (2010) (enacted). 
would harm retail investors because of the limited private judicial remedies provided by federal law in broker-customer disputes. ${ }^{42}$ To date, the SEC has not acted on this authority.

\section{B. FINRA Procedures}

Arbitrators in FINRA customer arbitrations are chosen through a party selection system. In 1998-2000, the time period from which our sample is chosen, customer claims for more than $\$ 50,000^{43}$ were resolved by threearbitrator panels consisting of two public arbitrators and one industry arbitrator.

FINRA does not impose limits on the background or professional ties of industry (non-public) arbitrators, and they generally include current and former brokers, bankers, and other professionals in the securities industry. ${ }^{44}$ On the other hand, public arbitrators, also known as neutrals, are supposed to be free of ties to the industry. At the time of our study, FINRA imposed relatively minimal restrictions through its definition of public arbitrator. The definition excluded individuals who had within the past three years been associated with a broker-dealer, who were registered or associated with a commodities dealer, as well as persons retired from such positions and employees of banks and other financial institutions that effect securities and commodities transactions. ${ }^{45}$ In addition, the rules excluded attorneys, accountants, and other professionals who, within the prior two years, had devoted twenty percent or more of their professional work to clients engaged in the foregoing business activities. ${ }^{46}$ Thus, at the time of our study, the pool of public arbitrators contained many individuals with non-trivial ties to the securities industry.

Both the inclusion of persons with securities industry ties in the pool of public arbitrators and the presence of an industry arbitrator on the panel have generated criticism of the FINRA arbitration process. ${ }^{47}$ On the one hand,

42 See Barbara Black, How to Improve Retail Investor Protection After the Dodd-Frank Wall Street Reform and Consumer Protection Act, 13 U.PA. J. Bus. L. 101, 103-06 (2010).

43 FINRA has now raised this limit to $\$ 100,000$. FINRA Notice 09-13, 2009 WL 572467 (effective March 30, 2009).

44 FINRA Code of Arbitration Procedure for Customer Disputes ("FINRA Code") $\$$ 10308(a)(4) (2008), available at http://finra.complinet.com/en/display/display_main.html?rbid=2403\&element_id=4066 \&filtered_tag=.

45 See Choi et al., supra note 5, at 113 n. 4.

46 Id.

47 See id. at 110. 
more knowledgeable arbitrators are likely to produce more accurate awards. Broker-customer disputes frequently involve technical issues in which familiarity with industry practices is valuable. Securities expertise enables an arbitrator to better understand the nature of the claims. ${ }^{48}$ As some courts have noted, "The most sought-after arbitrators are those who are prominent and experienced members of the specific business community in which the dispute to be arbitrated arose." 49 On the other hand, an arbitrator's connections to the industry - those same connections that may furnish expertise-may also raise concerns that those arbitrators may be predisposed against claimants. Moreover, an industry member's greater expertise may give their views undue weight with public members of the panel who lack such expertise.

In response to these concerns, FINRA amended the definition of a public arbitrator several times to restrict the permitted industry ties for public arbitrators. In 2004, for example, the National Association of Securities Dealers (NASD) (now FINRA) ${ }^{50}$ increased, from three years to five years, the amount of time necessary after leaving the securities industry to transition from a non-public to public arbitrator; clarified that "retired" broker dealers included anyone who spent a substantial part of his or her career in the industry; prohibited anyone who had been associated with the industry for at least twenty years from ever becoming a public arbitrator, regardless of how long ago the association ended; excluded attorneys, accountants, or other professionals whose firms have derived ten percent or more of their annual revenue in the previous two years from clients involved in securities-related activities, regardless of whether the excluded individual represented such clients; and provided that investment advisers may not serve as public arbitrators. ${ }^{51}$ FINRA also extended the industry exclusions to the spouse and immediate family members of an industry member. ${ }^{52}$

In 2007, FINRA further tightened the definition of public arbitrator to exclude persons who were employed by or served as an officer or director of

48 See Bradley J. Bondi, Facilitating Economic Recovery and Sustainable Growth Through Reform of the Securities Class-Action System: Exploring Arbitration as an Alternative to Litigation, 33 HARV. J.L. \& PUB. POL'y 607, 629, 630-31 (2010) (defending expertise of FINRA arbitrators).

49 Int'l Produce, Inc. v. A/S Rosshavet, 638 F.2d 548, 552 (2d Cir. 1981).

50 As noted above, the NASD was the predecessor to FINRA. Prior to the merger, approximately ninety percent of securities arbitrations were handled by the NASD; the remainder were arbitrated through the New York Stock Exchange arbitration program.

51 Order Granting Approval to a Proposed Rule Change Relating to Arbitrator Classification and Disclosure in NASD Arbittations, SEC Release No. 34-49573, 82 SEC Docket 2403, 2404 (April 16, 2004).

52 Id. 
a company in a control relationship with a broker-dealer, as well as the spouses and immediate family members of such persons. ${ }^{53}$ FINRA also clarified that persons registered through a broker-dealer could not be public arbitrators even if they were employed by a non-broker-dealer (such as a bank). ${ }^{54}$ In 2008, FINRA modified the professional disqualification rule to add a dollar limit in addition to the ten percent limit. Under the amendments, an attorney, accountant, or other professional was prohibited from serving as a public arbitrator if the individual's firm derived $\$ 50,000$ or more in annual revenue in the past two years from professional services rendered to certain industry entities relating to customer disputes concerning an investment account or transaction. ${ }^{55}$ Most recently, FINRA amended the definition of public arbitrator to exclude persons associated with a mutual fund or hedge fund from serving as public arbitrators and to require such individuals to wait for two years after ending their affiliations before being permitted to serve as public arbitrators. ${ }^{56}$

FINRA also responded to those who criticized the inclusion of an industry arbitrator on the panel..$^{57}$ In July 2008, FINRA announced the launch of a pilot program allowing customers to choose a panel consisting exclusively of public arbitrators. ${ }^{58}$ Although the number of arbitrations conducted under the pilot program was small, FINRA reported that investors won in a higher percentage of cases when the panel consisted of all public arbitrators. ${ }^{59}$ Accordingly, in 2010, FINRA filed a rule proposing a permanent

53 See Self-Regulatory Organizations; National Association of Securities Dealers, Inc; Order Approving Proposed Rule Change and Amendment No. 1 Thereto Relating to Amendments to the Classification of Arbitrators Pursuant to Rule 10308 of the NASD Code of Arbitration Procedure, Securities Exchange Act Release No. 54607 (October 16, 2006), 71 FR 62026 (October 20, 2006) (SR-NASD-2005-094) (approval order).

54 Id.

55 Order Approving Proposed Rule Change to Amend the Definition of Public Arbitrator, SEC Release No. 34-54792, 2008 WL 762967 (Mar. 13, 2008).

56 Order Approving Proposed Rule Change to Amend the Customer and Industry Codes of Arbitration Procedure to Revise the Public Arbitrator Definition, SEC Release No. 3469297, 2013 WL 1384506 (Apr. 4, 2013).

57 See STMicroelectronics, N.V. v. Credit Suisse Sec. (USA), LLC, 648 F.3d 68, 77 n.5 (2d Cir. 2011) (describing concerns about pro-industry bias and FINRA's response of offering all-public panels).

58 FINRA to Launch Pilot Program to Evaluate All-Public Arbitration Panels, FIN. Indus. REgUlATORY AU'TH. (July 24, 2008), http://www.finra.org/Newsroom/NewsReleases/2008/P038958.

59 Suzanne Barlyn, Finra to Propose Permanent Option of All-Public Arbitration Panels, WALL ST. J. (Sept. 29, 2010, $22: 01 \quad$ AM), http://online.wsj.com/news/articles/SB1000142405274870388240457551978248760454 8. 
option of all-public panels, ${ }^{60}$ which the SEC approved in February 2011.61 FINRA subsequently modified its rule to simplify the selection of an allpublic panel and to make this option available to either party. ${ }^{62}$ FINRA's website posts statistics comparing the results of arbitrations using all-public panels and reports that all-public panels granted awards to customers at a higher rate in 2011 and 2012 than panels including one non-public arbitrator, although the statistics reported for 2013 do not reveal a difference in win rates. ${ }^{63}$

In addition to the composition of FINRA panels, the process of choosing arbitrators is distinctive. Since November 1998, ${ }^{64}$ arbitrators have been chosen through a list selection system administered by the Director of Dispute Resolution, termed the Neutral List Selection System (NLSS). ${ }^{65}$ During the time period involved in our study, the NASD provided the parties in each case with two separate lists, one consisting of sixteen public arbitrators and the other consisting of eight industry arbitrators. The lists were generated by an NASD computer program using a rotational method, although the computer eliminated arbitrators with obvious conflicts of

60 Id. See also Order Granting Accelerated Approval of a Proposed Rule Change Relating to Amendments to the Panel Composition Rule, and Related Rules, of the Code of Arbitration Procedure for Customer Disputes, SEC Release No. 34-63799, 100 SEC Docket 1148 (Jan. 31, 2011) [hereinafter SEC Release No. 34-63799] (offering customers the option to choose an all-public panel in all cases).

61 SEC Approves FINRA Proposal to Give Investors Permanent Option of All Public Arbitration Panels, Fin. Indus. Regulatory Auth. (Feb. 1, 2011), http://www.finra.org/Newsroom/NewsReleases/2011/P122877.

62 See SEC Release No. 34-63799, supra note 48.

63 Dispute Resolution Statistics, FIN. INDUs. REGULATORY AutH., http://www.finra.org/ArbitrationAndMediation/FINRADisputeResolution/AdditionalR esources/Statistics/ (last visited May 29, 2014).

64 Prior to 1998, arbitrators were appointed by the NASD staff. Arbitrator Service Survey: Has List Selection Changed How Often Arbitrators Serve?, 2006 SEC. ARB. COMMENTATOR 1,1 (Feb. 2006), available at http://www.sacarbitration.com/pdf/Arbitrator $\% 20$ Service $\% 2000$ 05.pdf.

65 The NASD's Neutral List Selection System (NLSS) went into effect on November 17, 1998. The NLSS was proposed by the NASD Arbitration Policy Task Force as part of its 1996 Securities Arbitration Reform Report and modeled after the list selection system used by the American Arbitration Association. The report recommended that panels for larger cases continue to be composed of one industry member and two public arbittators. The report recommended improving the quality of arbitrators by increased arbitrator compensation, better training, expanding the arbitrator pool and requiring arbitrator evaluation of co-panelists. Press Release, NASD Regulation, SEC Apptoves List Selection Method for NASD Regulation Arbitration Forum (October 22, 1998), available at https://www.finra.org/Newsroom/NewsReleases/1998/P010433. 
interest. ${ }^{66}$ Along with the lists, the parties were also provided with background information on each arbitrator, including a copy of that arbitrator's Arbitrator Disclosure Report. ${ }^{67}$ NASD rules then allowed parties to strike, without cause, prospective panelists and required the parties to rank numerically the remaining arbitrators until they reached agreement on a panel. Importantly, list selection operated, at the time of our study, on a free strike basis, in which the parties were not limited in the number of prospective arbitrators they could strike. ${ }^{68}$ As a result, it was possible for the selection process to result in an incomplete panel. ${ }^{69}$ If this happened, the NASD would appoint an additional arbitrator selected randomly by computer, and the parties were not given the option of striking this additional arbitrator. ${ }^{70}$

FINRA subsequently changed this procedure in three significant ways. ${ }^{71}$ First, at the time of our study the public arbitrator ranked most highly by all the parties was appointed as chair of the panel. In 2006, FINRA adopted specific qualifications for panel chairs. ${ }^{72}$ To implement the qualification requirements, the list section system was modified to generate three separate lists of eight potential arbitrators: a chair-qualified list, another public list, and a non-public list. ${ }^{73}$ Then, in 2007, FINRA instituted limits on party strikeslimiting the parties to four strikes from each list of eight potential

66 The NASD shifted from a rotational method to a random selection method in 2005. Order Granting Accelerated Approval of Proposed Rule Change Relating to the Random Selection of Arbitrators by the Neutral List Selection System, SEC Release No. 34-51083 (January 26, 2005), available at www.sec.gov/rules/sro/nasd/34 51083.pdf.

67 See STMicroelectronics, N.V. v. Credit Suisse Sec. (USA) LLC, 648 F.3d 68, 72 (2d Cir. 2011) (describing selection process and Arbitrator Disclosure Reports). Parties were allowed to request additional information on the arbitrators, and the NASD director was required to forward that request to the arbitrators, although the arbitrators were not required to respond.

68 Self-Regulatory Organizations; Financial Industry Regulatory Authority, Inc.; Notice of Filing of Proposed Rule Change Relating to Amending the Codes of Arbitration Procedure to Increase the Number of Arbitrators on Lists Generated by the Neutral List Selection System, Securities Exchange Act Release No. 62134, (May 19, 2010), at 3, available at www.sec.gov/rules/sto/finra/2010/34-62134.pdf.

$69 \quad$ Id.

70 Id.

71 Paul A. Fischer \& Robin M. Sanders, How Changes To The NASD Code Of Arbitration Procedure May Affect Customer Arbitrations, Metro. Corp. Counsel (Aug. 1, 2007) http://www.metrocorpcounsel.com/articles/8629/how-changes-nasd-code-arbitrationprocedure-may-affect-customer-arbitrations.

72 To be "chair-qualified," an arbitrator was required to have a law degree or experience on at least three prior cases, as well as otherwise meet the definition of a public arbitrator.

73 Bailey Somers, SEC Ok's Updates to NASD Arbitration Code, LAw360 (January 24, 2007), http://www.law360.com/articles/17126/sec-ok-s-updates-to-nasd-arbitration-code. 
arbitrators. ${ }^{74}$ This change reduced the likelihood of an incomplete panel because some arbitrators were unable to serve or subsequently challenged for cause. To further address this concern, FINRA amended the selection system to expand the list of potential arbitrators from eight to ten in $2010 . .^{75}$

As noted above, our empirical study focuses on the 1998 to 2000 time period. Focusing on the 1998 to 2000 period as opposed to more recent arbitration awards allows us to test the need for the subsequent FINRA reforms and whether FINRA could have pursued less restrictive alternatives. Because our study focuses on a period of time when individuals could more easily qualify as public arbitrators, we are able to study the effect of arbitrator characteristics that, in some cases, FINRA now treats as disqualifying. We are also able to study whether legal representation for claimants may act as an alternative mechanism to address arbitrator bias.

Although FINRA has attempted to reduce arbitral bias through expanded grounds for disqualification, these reforms carry a cost—excluding potentially experienced and high-quality arbitrators from the pool of FINRA arbitrators. If attorneys for claimants can mitigate the negative impact of bias, FINRA's efforts may have been misdirected; focusing on representation for FINRA arbitration claimants may have done more to level the playing field.

\section{Prior Literature}

In addition to our own prior work, ${ }^{76}$ a few articles specifically study the FINRA arbitration process. ${ }^{77}$ Among the challenges faced by these studies is the absence of a baseline. Arbitration decisions rarely report details of the underlying claim, providing researchers with little basis for assessing case merits. As a result, the studies rely largely on survey data examining the extent to which arbitration participants report satisfaction with the system. ${ }^{78}$

74 Order Approving Proposed Rule Change and Amendments to Amend NASD Arbitration Rules for Customer Disputes; Order Approving Proposed Rule Change and Amendments to Amend NASD Arbittation Rules for Industry Disputes, SEC Release No. 34-55158 (January 24, 2007), available at http://www.sec.gov/rules/sto/nasd/2007/34-55158.pdf.

75 Order Approving Proposed Rule Change to Amending the Codes of Arbitration Procedure to Increase the Number of Arbitrators on Lists Generated by the Neutral List Selection System, SEC Release No. 34-62480 (July 9, 2010), available at http://www.sec.gov/rules/sro/finra/2010/3462480.pdf.

76 See Choi et al., supra note 5.

77 Id. at $116-19$.

78 See, e.g., Jill I. Gross \& Barbara Black, When Perception Changes Reality: An Empirical Study of Investors' Views of the Faimess of Securities Arbitration, 2008 J. Disp. Resol. 349, 380 (2008). 
Two recent studies go beyond participant satisfaction and collect information on arbitration process and outcomes. ${ }^{79}$ Both report a trend toward less favorable decisions for claimants. Jiro E. Kondo finds that, since the adoption of the party selection system by FINRA, selection of proindustry arbitrators has increased, and selection of arbitrators based on their expertise has declined.80 Lawrence S. Schultz finds a trend toward fewer customer wins. ${ }^{81}$

These trends may be due to the effect of party selection of arbitrators, which may favor brokerage firms, who are repeat players, in securities arbitrations. ${ }^{82}$ The repeat player advantage may include both the ability to screen potential arbitrators effectively and the ability to discipline arbitrators who rule against defendants by refusing to select them in subsequent cases. ${ }^{83}$ Alon Klement and Zvika Neeman hypothesize that arbitrators acting strategically in a private party selection system skew their decisions in order to increase the likelihood that they will be selected in the future. ${ }^{84}$ Such a bias would likely cause arbitrators to favor brokers rather than customers because brokers and their firms are more likely to participate in future cases, while customers are likely to be single-shot litigants. We explore this possibility in our empirical analysis by focusing on the decisions of both professional and retired arbitrators.

\section{Party Selection and the Judicial Decision-making Literature}

Studies of the FINRA arbitration process have paid little attention to the party selection system and its relationship to the literature on judicial decision-making. A substantial literature explores the relationship between particular judicial characteristics and the outcomes of cases that they decide. ${ }^{85}$

79 Kondo, supra note 13; Laurence S. Schultz, Storm Clouds in Arbitration, 15 PIABA B.J. 16, 21 (2008).

$80 \quad$ Kondo, supra note 13.

81 Schultz, supra note 79.

82 Alexander J.S. Colvin, An Empirical Study of Employment Arbitration: Case Outcomes and Processes, 8 J. EMP. LEG. STUD. 1, 21 (2011) (reporting strong evidence of repeat player advantage in employment arbitration).

83 See, e.g., John O'Donnell, The Arbitration Trap: How Credit Card Companies Ensnare Customers, Pub. Citizen (Sept. 2007), http://www.citizen.org/publications/publicationredirect.cfm?ID $=7545$.

84 Alon Klement \& Zvika Neeman, Private Selection and Arbitrator Impartiality, Soc. ScI. RESEARCH CTR. (March 31, 2011), http://sstn.com/abstract=1800026.

85 See, e.g., Ric Simmons, Chooseyourjudges.org: Treating Elected Judges as Politicians, 45 AKRON L. REV. 1, 20 (2012) (observing that "legal and political science scholars have conducted hundreds of studies on the voting behavior of judges"). 
The majority of these studies seek to analyze the relationship between judicial ideology and voting outcomes. ${ }^{86}$ An important study by William Landes and Richard Posner comprehensively analyzes the relationship between ideology and judicial voting behavior over a seventy-seven year period. ${ }^{87}$ Like many similar studies, Landes and Posner report a correlation between ideology and voting, although they note that the correlation depends heavily on the context. $^{88}$ Studies also focus on the effect of other judge-specific characteristics such as race and gender on judicial voting or case outcomes. These studies reach mixed results-some document racial or gender differences; others do not find significant differences. ${ }^{89}$

Landes and Posner also demonstrate the presence of group or panel effects, such as conformity and polarization, in cases involving panels with more than one judge, such as the U.S. Courts of Appeals and the Supreme Court. ${ }^{90}$ Other studies document collegial effects, suggesting that a focus on individual judicial preferences or characteristics may be too narrow. ${ }^{91}$ We address the potential for panel effect in our study by collecting and coding for characteristics of individual arbitrators. Because of the potentially more significant role of the panel chair, we also code characteristics of the chair and the second public arbitrator separately.

86 Studies also look at particular aspects of a judge's background or experience. See, e.g., Michael C. Dorf, Does Federal Executive Branch Experience Explain Wby Some Republican Supreme Court Justices "Evolve" and Others Don't?, 1 HARV. L. \& POL'Y REV. 457, 462-67 (2007) (concluding that Supreme Court Justices without prior judicial experience tend to become more liberal, while those with prior judicial experience do not).

87 William M. Landes \& Richard A. Posner, Rational Judicial Behavior: A Statistical Study, $1 \mathrm{~J}$. LEGAL ANALYSIS 775 (2009). Landes and Posner coded information on judicial gender and race, and found no correlation between these variables and voting behavior. Id. at 811. In unreported regressions, we analyze the effect of arbitrator gender on case outcomes and find no significant relationship.

88 Id. at 822-25. A prominent earlier study failed to find a significant relationship between judicial characteristics and outcomes in a large sample of civil rights cases. Orley Ashenfelter, Theodore Eisenberg \& Stewart J. Schwab, Politics and the Judiciary: The Influence of Judicial Background on Case Outcomes, 24 J. LEGAL STUD. 257, 281 (1995).

89 See, e.g., Pat K. Chew \& Robert E. Kelley, The Realism of Race in Judicial Decision Making: An Empirical Analysis of Plaintiffs' Race and Judges' Race, 28 HARV. J. ON RACE \& ETHNIC JusT. 91 (2012) (exploring the effect of judicial race on case outcomes); Jennifer L. Peresie, Note, Female Judges Matter: Gender and Collegial Decisionmaking in the Federal Appellate Courts, 114 YALE L.J. 1759, 1762-68 (2005) (describing various studies on the effect of gender on case outcomes).

90 Landes \& Posner, supra note 71 at 818-21.

91 See Harry T. Edwards, The Effects of Collegiality on Judicial Decision Making, 151 U. PA. L. REv. 1639, 1652-62 (2003); Lewis A. Kornhauser \& Lawrence G. Sage, The One and the Many: Adjudication in Collegial Courts, 81 CALIF. L. REV. 1, 6-9 (1993). 
We also note that the decision makers in the FINRA system function as a type of hybrid between a judge and a jury. The potential effect of juror experience as well as race, gender, and other juror characteristics has led to a complex system of jury selection. Given the potential significance of juror selection, a literature has developed on the extent to which it is appropriate for parties to consider certain characteristics in the selection or challenge of jurors. ${ }^{92}$ The parties to a FINRA arbitration participate in the selection of the arbitrators, just as litigants do in the selection of juries, but not judges. The party selection system raises the additional question, not presented by the judicial decision-making literature, of whether party selection can mitigate or eliminate the effect of characteristics that might bias the decision maker.

\section{HYPOTHESES}

Our hypotheses relate to a variety of characteristics that arbitrators bring with them to the arbitration process. They are limited, of course, by our ability to obtain data about individual arbitrators. The hypotheses are based on the prior literature as described above, conversations with a number of lawyers experienced in securities arbitration, our own experience testifying as expert witnesses in arbitration cases, and our conjectures drawn from the disclosures provided to the parties pursuant to the arbitrator selection process.

As discussed in Section 2.2, FINRA procedures during our sample period allowed arbitrators with certain connections to the securities industry to serve as public arbitrators. Individuals who would be treated as industry arbitrators under current rules were then treated as public arbitrators, either because their work for the securities industry fell below a certain minimum threshold of their overall business, or because they had retired from the industry and more than three years had elapsed since their retirement. Arbitrator disclosure forms, however, required the disclosure of industry experience. This information was provided to the parties, enabling the parties to strike arbitrators with these conflicts from the panel. As noted above, FINRA's definition of public arbitrator has subsequently been tightened to make it harder for persons associated at any time with the securities industry to serve as public arbitrators. ${ }^{93}$

92 See Albert W. Alschuler, Racial Quotas and the Jury, 44 Duke L.J. 704, 717-18 (1995).

93 See supra notes 51-56 and accompanying text (describing changes to FINRA's definition of public arbitrator). 
Hypothesis 1: Arbitrators with connections to the securities industry will make smaller awards.

Many arbitrators' professional backgrounds reveal substantial industry experience, but not specific ties to the brokerage industry. Examples include academics, regulators, attorneys engaged in transactional securities work, and attorneys who primarily represented investors. These other sources of securities experience are unlikely to be correlated with significant industry bias. Indeed, to the extent that these arbitrators represent investors in other proceedings, their predisposition may be pro-customer rather than proindustry. Thus, securities experience could cut either way, leading arbitrators to be predisposed toward either the industry or the investor-claimants.

In addition, securities experience may give an arbitrator a more sophisticated understanding of the issues involved in the case. As a result, and because reported awards do not contain sufficient information for us to benchmark or predict the size of an expected award, it is difficult to determine the significance of differences in arbitration awards issued by panels that reflect greater securities experience. Nonetheless, particularly in light of the fact that critics and FINRA itself appear to have viewed the potential for anti-customer bias as most significant, ${ }^{94}$ we postulate that experience in the securities industry is more likely to make the arbitrator more sympathetic to the industry.

\section{Hypothesis 2: Professional arbitrators will make smaller awards.}

Some research has questioned the effect of arbitrator incentives, in particular the desire to be selected as an arbitrator in future cases. For example, as noted above, Klement and Neeman hypothesize that arbitrators tailor their awards to influence the perception of future parties. ${ }^{95}$ If arbitrators want to be selected in future cases, they may skew arbitration awards in favor of industry parties who are repeat players in securities arbitration. This effect is likely to be greatest for professional arbitrators-those who devote substantially all of their time to serving as arbitrators. Arbitrators whose primary vocation is not dispute resolution and who serve as arbitrators only occasionally are less likely to be influenced by the concern that their decisions will affect their likelihood of being selected in future cases.

94 Id. It is noteworthy that none of FINRA's changes to the definition of public arbitrator have attempted to address potential bias by arbitrators against the securities industry.

95 Klement \& Neeman, supra note 84 at $1-3$. 
Hypothesis 3: Retired arbitrators will make smaller anards.

Another category of public arbitrators who may be anxious to be selected as arbitrators are retired people. In addition to having a lower opportunity cost for their time, our conversations with retired arbitrators suggested that serving as an arbitrator was an interesting diversion that got them out of the house. The relatively modest honorarium that arbitrators receive may also be more economically important to a retired person who lacks a regular income. A willingness to serve would give retired arbitrators an incentive similar to that of professional arbitrators to curry favor with brokerage firms, who are the repeat players in this process. Alternatively, some attorneys suggested to us that older arbitrators may be more conservative, and therefore reluctant to make large awards. Both of these factors suggest that older arbitrators would tend to make lower awards.

Hypothesis 4: Arbitrators with prior experience as regulators will make larger awards.

We are also interested in the effect of an arbitrator's experience as a regulator on their awards. Regulators, who by the nature of their work deal with a disproportionate number of wrongdoers, may develop a skepticism toward the industry. Our hypothesis is that arbitrators with prior government experience are likely to give more credence to claims of broker misconduct and/or see greater need to deter such misconduct through larger awards.

Hypothesis 5: Arbitrators who are compliance officers will make larger rewards.

Compliance officers play a quasi-regulatory role within brokerage firms. In general, compliance officers are responsible for overseeing employee screening, licensing, and trading, monitoring firm operational practices and risk management, overseeing programs to safeguard customer information and funds, and implementing programs to prevent misconduct, such as money laundering and insider trading. ${ }^{96}$ In the course of this work,

96 See James A. Fanto, Advising Compliance in Financial Firms: A New Mission for the Legal Academy, 8 BROOK. J. CORP. FIN. \& COM. L. 1, 12 n. 56 (2013) (explaining that compliance officers "oversee the screening process and background checks for employees, as well as their licensing and qualifications; they establish and oversee anti-money laundering and Foreign Corrupt Practices Act programs; they establish control programs for the safeguarding of customer nonpublic personal information; and they oversee procedures designed to prevent insider trading and other conflicts of interest"); see generally SEC. Indus. \& Fin. Mkts. Ass'n, The Evolving Role of Compliance 2-5, 24-28 (2013), 
compliance officers are exposed to a wide range of actual and potential broker misconduct. As a result, we conjecture that service as a compliance officer, like past experience as a regulator, would cause arbitrators to be more sympathetic to customer claims of broker misconduct and, as a result, to grant larger awards.

Hypothesis 6: The effects of the characteristics in Hypotheses 1 through 5 will be reduced if the claimant/respondent are represented by counsel.

As discussed above, party selection could conceivably reduce or eliminate the effects described in Hypotheses 1 through 5; the information suggesting the potential for arbitrator bias is available to the parties at the time that they select the arbitration panel. We expect that parties are most likely to use this information if they are represented by counsel. We postulate that attorneys experienced in securities arbitration would have a sense of how these characteristics are likely to affect their clients' case and would select arbitrators accordingly, with the caveat that the limited pool of arbitrators provided to the parties constrains their ability to select their ideal panel.

\section{EMPIRICAL TESTS}

\section{A. Description of Dataset}

We obtained NASD arbitration awards from the FINRA arbitration awards online site and from the LEXIS database. To generate a random set of arbitrators, we randomly selected 417 arbitration awards involving investor claimants for the years 1998 to 2000 . We then limited our sample to arbitration decisions that followed a hearing ${ }^{97}$ with a three-person panel, thus excluding awards made by a single arbitrator. We only looked at arbitrations where the chair and one panel arbitrator were public arbitrators and the other panel arbitrator was an industry arbitrator. The decisions identified the

available

http://www.wilmerhale.com/uploadedFiles/WilmerHale_Shared_Content/Files/PDFs/

SIFMA-evolving-role-of-compliance-2013.pdf on the role of the compliance officer.

97 A substantial percentage of arbitration claims are settled or resolved on the papers without a live hearing. FINRA's website reports, for example, that for the period from $2010-2014$, fewer than $20 \%$ of cases are resolved after a hearing, and that the majority of cases are resolved through settlement. See Dispute Resolution Statistics, FINRA ARBITRATION AND MEdiation, (Aug. 24, 2014, 11:07 ,http://www.finra.org/ArbitrationAndMediation/FINRADisputeResolution/AdditionalR esources/Statistics/. 
members of the panel as well as indicated the arbitrator who served as the panel chair. ${ }^{98}$ We removed arbitration awards where the arbitration resulted solely in an unreported settlement; we included awards that reported a settlement amount, as well as awards that gave a monetary award but also had a partial unreported settlement. We also removed awards where we lacked information on the amount of claimed compensation. This left us with a sample of 381 observations.

Next, we collected data on the background of each of the arbitrators in our sample from the arbitrator disclosure reports that we were able to obtain, which we supplemented with information from other sources, such as the Internet. We were able to obtain background data on approximately twothirds of the arbitrators appearing in our arbitration sample. Table 1 reports the number of arbitration awards in our sample by year.

Table 1. Arbitrations by Year

\begin{tabular}{lcc}
\hline Year & Freq. & Percent \\
\hline 1998 & 137 & 36.0 \\
1999 & 119 & 31.2 \\
2000 & 125 & 32.8 \\
Total & 381 & 100.0 \\
\hline
\end{tabular}

\section{B. Variable Description}

The dependent variable for our tests is the Compensation Ratio, defined as the compensatory award (or settlement, if reported) divided by the requested compensation amount. ${ }^{99}$ One potential weakness in this measure is that the claimant decides how much to request as compensation, which creates room for exaggeration. For example, claimants may request punitive or exemplary damages as well as damages for pain and suffering. However, these are listed

98 Because of FINRA's selection procedures at the time of our study, the chairs are almost all public arbitrators. In some cases, for reasons that we are unable to ascertain, decisions in our sample reported that the panel was chaired by an industry arbittator. We excluded arbitrations with non-public chairs from the sample.

99 We use the Compensation Ratio, rather than the absolute level of compensation awarded, as our dependent variable because we lack data on the actual damages suffered by the claimants. Using the ratio rather than the raw figure mitigates the omitted variable problem. 
separately in the arbitration award, which allows us to exclude them from our measure of the requested compensatory amount. The requested compensatory amount will typically turn on the number of securities involved in a particular transaction multiplied by the losses the investor-claimant incurred on the securities. Because information on the quantity of securities traded (as well as the increase or decline in share price) is objective and easily verifiable by the broker or brokerage firm respondent, claimants have limited discretion with respect to the amount of compensation requested in that respect.

A number of additional factors may affect the Compensation Ratio. To control for these factors, our models include variables relating to the subject matter of the dispute, selection of the dispute for arbitrator resolution, award, and state in which the arbitration occurred. A list of the variable definitions is provided in the Appendix.

Subject matter controls include indicator variables for six common areas of arbitration. Suitability is defined to equal one if the arbitration involved a suitability claim, including claims relating to NYSE Rule 405 "know your customer"100 and FINRA Rule 2111 (formerly NASD Rule 2310) issues, ${ }^{101}$ and zero otherwise. Other subject matter indicator variables include Churning (a churning, excessive trading, or excessive commission claim), Unauthorized Trades, Failure to Execute (a failure to buy or sell as directed), Misrepresentation, and Conversion (a claim of theft, conversion, unauthorized withdrawals, or selfdealing). The base category consists of claims involving a non-specified breach of contract or violation of fiduciary duty. Table 2 reports on the frequency of the subject matter claims in our arbitration sample. Misrepresentation (72\%) and suitability (47\%) claims are the most common.

100 The "know your customer" rule requires member firms to "[u]se due diligence to learn the essential facts relative to every customer [and] every order." Diligence as to Accounts, NYSE Rule 405(1) (Sept. 8, 2008), available at http://nyserules.nyse.com/NYSETools/bookmark.asp?id=sx-policymanualnyseConductofAccountsR $401414 \&$ manual $=/$ nyse/rules/nyse-rules $/$.

101 The "suitability requirement" states, "A member or an associated person must have a reasonable basis to believe that a recommended transaction or investment strategy involving a security or securities is suitable for the customer, based on the information obtained through the reasonable diligence of the member or associated person to ascertain the customer's investment profile. A customer's investment profile includes, but is not limited to, the customer's age, other investments, financial situation and needs, tax status, investment objectives, investment experience, investment time horizon, liquidity needs, risk tolerance, and any other information the customer may disclose to the member or associated person in connection with such recommendation." FINRA Rules $₫ 2111$ (a) (2014), available http:// finra.complinet.com/en/display/display.html?tbid=2403\&element_id=9859. 
We also include controls to address selection effects. Table 2 reports on the settlements in our sample. The vast majority of settlements are unreported; our sample includes a small number of settlements that are reported - typically because only some of the respondents have settled. ${ }^{102}$ In those cases, the reported decision may or may not report the settlement terms. The variable Reported Settlement is defined to equal one where the arbitration resulted in a full or partial settlement and the settlement amount was reported as part of the arbitration award (and included therefore in the Compensation Ratio variable) and zero otherwise. Unreported Partial Settlement is defined to equal one where the arbitration resulted in a partial settlement for an unreported amount, and the award (if any) against the remaining nonsettling respondents was reported and zero otherwise. We expect that awards in the case of an Unreported Partial Settlement should be lower due to the settlement by a subset of the respondents, although the partial settlement may correlate with the strength of the case.

Table 2 also provides summary statistics on our opinion controls. Opinion controls focus on characteristics of the claim that may affect the Compensation Ratio. Claimed Compensation is included because the absolute level of compensation requested may affect the Compensation Ratio awarded. Arbitrators may be less willing to grant a higher Compensation Ratio for larger Claimed Compensation amounts, all other things being equal, simply because they are reluctant to award large sums. Moreover, arbitrators may perceive a large award against an individual broker or small firm as posing a risk of insolvency. The mean Claimed Compensation for our sample is $\$ 291,000$, but the median is a much more modest $\$ 90,000$. The Compensation Ratio is less skewed, with a mean award of $38 \%$ of the claim and a median of $22 \%$. To account for possible non-linearity in the relationship between Compensation Ratio and Claimed Compensation, we also include a squared term for Claimed Compensation.

We include a control variable for arbitrator experience: Inexperienced is set to one if the award is from the first year that the arbitrator appeared in the dataset and zero otherwise. Arbitrators new to the job may be reluctant to make large awards because it may reduce their chances for future selection by brokerage firms and their attorneys-the repeat players in securities arbitrations.

102 The strength of cases that settle may be different from those that do not settle. Moreover, the claimants who settle are arguably more risk averse than those that do not, which may affect their investment decisions as well. 
As an additional control, we include Top Accused Brokerage, which is set to one if any of the respondents were one of the top ten brokerage firms as of 1998. ${ }^{103}$ A large brokerage firm may have repeat player advantages and greater resources in defending those complaints, leading to lower awards.

Several opinion controls deal with the strength of the case; stronger cases should result in a higher Compensation Ratio. Unfortunately, we have no direct measure of the strength of a claimant's case, so we rely on three proxies. First, Respondent Failed to Appear is set to equal one if the any of the respondents failed to appear at the arbitration hearing and zero otherwise. Respondents may not appear if their case is weak. Alternatively, Respondents' failure to appear may lead the arbitrators to view their case as less meritorious. In most cases, a default award will be entered against the non-responding party. At least one respondent failed to appear in $23 \%$ of the awards in our sample.

Second, we use a claimant's claim for punitive damages (Claimed Punitive Damages) as a proxy for a relatively strong case. ${ }^{104}$ Although punitive damages can be (and are) claimed in connection with each of the claim types in our classification, we hypothesize that claimants request punitive damages in cases involving more egregious wrongdoing or where they have hard evidence of fraud or other culpable misconduct. Many awards request an unspecified amount of punitive damages. This measure may be relatively noisy, as some lawyers will request punitive damages in every case, while others never do. We set Claimed Punitive Damages as equal to one, however, only when the claimant has claimed punitive damages with some specificity. Two situations fall within this definition: (a) if the claimant requests a positive dollar amount of punitive damages-fixing in the arbitrator's minds a precise amount of punitive damages; and (b) if the award includes punitive damages, indicating that the claimant pressed their claim for punitive damages during the hearing.

Third, our last proxy for the strength of the case, Claimed CRD Expungement, is set to one if the respondents requested that the Central Registration Depository ("CRD") record of any of the respondent-brokers be

103 Sec. Indus. Ass'n, Securities Industry Yearbook 1998-99, 6-7 (1998).

104 Punitive damages are intended to punish the wrongdoer rather than to compensate the victim and are awarded in cases of particularly egregious misconduct. See, e.g., F. Warren Jacoby, The Relationship of Punitive Damages and Compensatory Damages in Tont Actions, 75 DiCK. L. Rev. 585, 587 (1970) ("Punitive damages are not intended to remunerate the injured party for the damages he may have sustained. They are not to compensate; they are the penalty the law inflicts for gross, wanton, and culpable negligence, and are allowed as a warning or as an example to defendant or others."). 
expunged, and zero otherwise. ${ }^{105}$ FINRA maintains CRD records for active brokers reflecting customer complaints and disciplinary proceedings. ${ }^{106}$ Arbitrators may, at their discretion, choose to expunge the arbitration claim from the CRD records for a broker involved in arbitration, subject to judicial confirmation. ${ }^{107}$ We treat a respondent as requesting CRD expungement if: (a) the respondent requested the expungement in the award summary; or (b) there is an award of CRD expungement, indicating that the respondent actively pursued expungement during the arbitration hearings. We treat a request for CRD expungement as an indication that the respondents' case was stronger relative to the claimants' case. We consider this proxy to be the noisiest of the three case strength proxies in light of the consistent criticisms leveled at arbitration panels for awarding expungement without an adequate basis. ${ }^{108}$

To measure the complexity of the arbitration, we include in our opinion controls the number of hearings in the arbitration (Number of Hearings) and the length of the arbitration opinion (Opinion Length). Finally, our models include geographic controls for the state in which the arbitration hearing took place, which we treat as exogenous to the variables in our dataset. We include indicator variables for the three states with the most arbitrations (New York, California, and Florida).

In Hypothesis H6, we postulate that the presence of an attorney may have an effect on panel selection, which may in turn relate to arbitration outcomes. To assess this possibility, we include in certain models indicator variables coded as one if the claimant is represented by counsel (Claimant Attorney) or the respondent is represented by counsel (Respondent Attorney), and

105 Customer complaints against brokers are reported in FINRA's CRD database and available to the public to review by request. See SEC. \& ExCH. Comm'n, Protect Your MONEY: Check OUt BROKERS AND INVESTMENT Advisers (2013), available at

$106 \quad I d$ http://www.sec.gov/investor/brokers.htm (describing CRD database).

107 Under FINRA rules, courts may confirm expungement orders requiring FINRA be named as a party only if "(A) the claim, allegation or information is factually impossible or clearly erroneous"; "(B) the registered person was not involved in the alleged ... violation"; or "(C) the claim, allegation or information is false." FINRA Rules $\$$ 2080(b)(1) (2009), available at http://finra.complinet.com/en/display/display_main.html?tbid=2403\&element_id=8468 - Despite the limited grounds available for expungement, one study reports that arbitration panels routinely grant expungement requests. See Jean Eaglesham \& Rob Barry, Brokers Able to Hide Some Disputes, Wall ST. J. (Oct. 17, 2013.), available at http://online.wsj.com/news/articles/SB2000142405270230368040457913952010008336 0.

108 See Eaglesham \& Barry, supra note 107. 
zero otherwise. In addition, better representation may lead directly to better outcomes. Indeed, representation may correlate with case strength-claimants with strong cases are more likely to be able to attract an attorney to work on a contingency fee basis, while respondents with no defenses may not bother to hire counsel. Claimants were represented by counsel in $87 \%$ of the cases; respondents were represented in $82 \%$.

Table 2. Summary Statistics

\begin{tabular}{lcccc}
\hline Variable & $\mathbf{N}$ & Mean & Median & $\begin{array}{c}\text { Standard } \\
\text { Deviation }\end{array}$ \\
\hline Award (\$ Thousands) & 381 & 59.1 & 15.9 & 128.9 \\
Compensation Ratio & 381 & 0.343 & 0.144 & 0.388 \\
Claimant Attorney & 381 & 0.866 & 1.000 & 0.341 \\
Respondent Attorney & 381 & 0.829 & 1.000 & 0.377 \\
Suitability & 381 & 0.465 & 0.000 & 0.499 \\
Churning & 381 & 0.213 & 0.000 & 0.410 \\
Unauthorized Trades & 381 & 0.328 & 0.000 & 0.470 \\
Failure to Execute & 381 & 0.179 & 0.000 & 0.383 \\
Misrepresentation & 381 & 0.722 & 1.000 & 0.449 \\
Conversion & 381 & 0.037 & 0.000 & 0.188 \\
Reported Settlement & 381 & 0.005 & 0.000 & 0.072 \\
Unreported Partial Settlement & 381 & 0.045 & 0.000 & 0.207 \\
Claimed Compensation $\$$ & 381 & 0.291 & 0.090 & 0.850 \\
millions) & & & & \\
Inexperienced & 381 & 0.108 & 0.000 & 0.310 \\
Top Accused Brokerage & 381 & 0.092 & 0.000 & 0.289 \\
Respondent Failed to Appear & 381 & 0.218 & 0.000 & 0.413 \\
Claimed Punitive Damages & 381 & 0.307 & 0.000 & 0.462 \\
Claimed CRD Expungement & 381 & 0.150 & 0.000 & 0.357 \\
Number of Hearings & 381 & 5.462 & 5.000 & 4.209 \\
Opinion Length & 381 & 4.625 & 4.000 & 1.160 \\
New York & 381 & 0.142 & 0.000 & 0.349 \\
California & 381 & 0.226 & 0.000 & 0.419 \\
Florida & 381 & 0.118 & 0.000 & 0.323 \\
\hline
\end{tabular}




\section{Industry Experience}

Our first test attempts to disaggregate the effects of experience and expertise by focusing on industry connections. We create an indicator variable, Securities Experience, which is set equal to one if the arbitrator was primarily employed in the securities industry during the course of his or her career or if the individual had done work for firms in the securities industry in the five years prior to the arbitration, regardless of the amount; if not, the variable equals zero. Table 3 reports the incidence of securities experience among the public arbitrators in our sample. We classify the arbitrators according to their position on the panel, distinguishing the public arbitrators selected to be the Arbitration Chair from those serving in the second panel position. At the time of our study, both the chair and the panel would have been drawn from the same list of public arbitrators, but the chair would have been ranked more highly by the parties, suggesting a greater consensus as to that arbitrator.

Table 3. Industry Experience for Public Arbitrators

\begin{tabular}{lcc}
\hline & $\mathrm{N}$ & $\begin{array}{c}\text { Fraction with } \\
\text { Securities } \\
\text { Experience }\end{array}$ \\
\hline Chair & 261 & 0.180 \\
Panel & 250 & 0.192 \\
\hline
\end{tabular}

The incidence of connections to the securities industry is surprisingly high for individuals classified as public arbitrators. Recall that the connections are disclosed on the arbitrator's disclosure form and arbitrators can be struck for any reason. Nonetheless, $18.0 \%$ of the arbitrators serving as chairs had some connection to the industry, along with $19.2 \%$ of the arbitrators serving in the panel position.

To test the importance of the public arbitrators' connections to the securities industry, we estimate the following equation for each award using ordinary least squares and robust standard errors:

$$
\begin{aligned}
& \text { Compensation Ratio }{ }_{i}=a+\beta_{\text {Hi }} \text { Securities_Industry_Chair }_{i} \\
& +\beta_{2 i} \text { Securities_Industry_Panel }+\sum \beta_{j i}{\text { Subject Matter } \gamma_{j i}} \\
& +\sum \beta_{k i} \text { Opinion Controls } k_{k i}+\sum \beta_{i j} \text { State Controls }_{l i}+\text { Year Effects }+\varepsilon_{i}
\end{aligned}
$$

Model 1 of Table 4 reports our results. 
Table 4. Industry Experience Regressions

\begin{tabular}{|c|c|c|}
\hline & (1) & (2) \\
\hline Securities Experience Chair & $\begin{array}{l}-0.413 \\
(-0.46)\end{array}$ & $\begin{array}{l}-1.309 \\
(-0.45)\end{array}$ \\
\hline Securities Experience Panel & $\begin{array}{l}-0.374 \\
(-0.52)\end{array}$ & $\begin{array}{l}-4.558^{* *} \\
(-2.71)\end{array}$ \\
\hline Claimant Attorney & & $\begin{array}{l}-0.346 \\
(-0.39)\end{array}$ \\
\hline Respondent Attorney & & $\begin{array}{l}-1.689 \\
(-1.51)\end{array}$ \\
\hline $\begin{array}{l}\text { Securities Experience Chair } \\
\text { * Claimant Attorney }\end{array}$ & & $\begin{array}{l}1.056 \\
(0.34)\end{array}$ \\
\hline $\begin{array}{l}\text { Securities Experience Panel } \\
* \text { Claimant Attorney }\end{array}$ & & $\begin{array}{l}4.989^{*} \\
(2.60)\end{array}$ \\
\hline Constant & $\begin{array}{l}-1.658 \\
(-1.16) \\
\end{array}$ & $\begin{array}{l}0.120 \\
(0.06) \\
\end{array}$ \\
\hline$N$ & 186 & 186 \\
\hline Adj. $R^{2}$ & 0.310 & 0.341 \\
\hline Subject Matter Controls & Yes & Yes \\
\hline Opinion Controls & Yes & Yes \\
\hline State Controls & Yes & Yes \\
\hline
\end{tabular}

Note. Dependent variable for OLS regressions is the log odds of the compensation ratio. Variable definitions are in the Appendix. T-statistics are in parentheses. F-test for Securities Experience Chair + Securities Experience Chair $*$ Claimant Attorney $=0.7866$. F-test for Securities Experience Panel + Securities Experience Panel $*$ Claimant Attorney $=0.5474$.

+ Coefficient significant at the $10 \%$ level or less.

${ }^{*}$ Coefficient significant at the $5 \%$ level or less.

${ }^{*}$ Coefficient significant at less than the $1 \%$ level.

We find that the coefficients for Securities Industry Chair and Securities Industry Panel are both negative, but neither is significant. This finding does 
not support the hypothesis (Hypothesis 1) that panels with public arbitrators who have connections to the securities industry tend to provide lower awards.

The potential for bias presented by affiliation with the securities industry seems rather obvious, but the results in Model 1 suggest that it may not affect outcomes. Nonetheless, given the role that the parties play in arbitrator selection, it is difficult to understand why a claimant would ever allow an arbitrator with connections to the industry to serve as a public arbitrator on a panel. One reason may be that the claimant is not fully using the benefits of the party selection process. Claimants, after all, are likely to be one-shot players, and the party selection process differs from many other types of dispute resolution. The use of claimants' counsel, who can add experience in party selection, may be valuable here, and we hypothesize that counsel may play an important role in the process by which panels are selected. To assess this possibility, we estimate the model again, this time adding variables for Claimant Attorney, Respondent Attorney, and interaction variables for Securities Experience Cbair*Claimant Attorney and Securities Experience Pane ${ }^{*}$ Claimant Attorney. The interaction variables allow us to assess separately the effect of connection to the securities industry on claimants who are represented by counsel and those who are unrepresented. We present the results in Model 2 of Table 4.

The results strongly support the hypothesis that unrepresented claimants see lower awards when public arbitrators have connections to the securities industry. The Securities Experience Panel coefficient captures the effect of this characteristic on claimants who are unrepresented. It is negative in Model 2 with considerably greater magnitude than in Model 1. Moreover, the coefficient estimate in Model 2 is significant at the $1 \%$ confidence level. The coefficient for the interaction variable Securities Experience Panel*Claimant Attorney, when summed with Securities Experience Panel, captures the effect of this characteristic on claimants who have representation. The coefficient for the interaction variable is positive and significant and the sum of the Securities Experience Panel and Securities Experience Panel*Claimant Attomey is not significantly different from zero (as reported in the F-test in the legend). This finding suggests that lawyers play an important role in screening out even obvious conflicts of interest. Conversely, unrepresented claimants appear to be at a disadvantage in protecting themselves against conflicts of interest. ${ }^{109}$

109 We also looked at whether the chair or panel arbitrator was working in a securities firm or as a banker at the time of the arbittation (Profession Securities-Banker). We te-estimated Model 2 of Table 4, replacing Securities Experience Chair and Securities Experience Panel and their interaction terms with corresponding variables for Profession Securities-Banker Chair 


\section{Professional Arbitrators}

The results presented in Table 4 suggest that arbitrators with connections to the securities industry tend to make lower awards. The effect of that conflict of interest is essentially eliminated, however, when claimants are represented by counsel. What about less obvious conflicts of interest? Do they influence awards? If so, is that influence ameliorated by the presence of counsel?

As indicated above, some commentators argue that arbitrators are motivated by a desire to be selected in future cases. They hypothesize that such arbitrators will tend to make lower awards in an effort to be more attractive to respondents, who are typically repeat players (Hypothesis 2). Our second test examines whether these professional arbitrators behave differently from other arbitrators. To assess this possibility, we create an indicator variable, Professional Arbitrator, coded to equal one if the arbitrator devotes substantially all of his or her professional time to arbitration and mediation or is described as self-employed, and zero otherwise. Table 5 reports the incidence of professional arbitrators among the public arbitrators in our sample. Professional arbitrators constitute $34.6 \%$ of the chairs, arguably the most influential position, and $25.2 \%$ of the other public arbitrators.

Table 5. Professional Arbitrators

\begin{tabular}{ccc}
\hline & $\mathrm{N}$ & $\begin{array}{c}\text { Fraction } \\
\text { Professional } \\
\text { Arbitrators }\end{array}$ \\
\hline Chair & 312 & 0.346 \\
Panel & 278 & 0.252 \\
\hline
\end{tabular}

and Profession Securities-Banker Panel. Unreported, the coefficient on Profession SecuritiesBanker Chair and Profession Securities-Banker Panel are negative, similar with Model 2, but only Profession Securities-Banker Chair is significant (at the 1\% level). The interaction terms with Claimant Attomey are positive, similar with Model 2 of Table 4, but not significantly different from zero. The sum of Profession Securities-Banker Chair and the Profession SecuritiesBanker Chair* Claimant Attomey is negative and significant at the $10 \%$ level. The sum of Profession Securities-Banker Panel and the Profession Securities-Banker Panel*Claimant Attomey is not significantly different from zero. While a Claimant Attorney can mitigate the impact of an arbitrator (this time the Chair) that works in the securities industry or as a banker, the overall effect, as indicated by the sum of Profession Securities-Banker Chair and the Profession Securities-Banker Chair*Claimant Attomey, is negative. 
We estimate the following equation for each award using ordinary least squares and robust standard errors:

$$
\begin{aligned}
& \text { Compensation Ratio }=a+\beta_{1} \text { Professional_Arbitrator_Chair }_{i} \\
& +\beta_{2 i} \text { Professional_Arbitrator_Panel }+\sum \beta_{j i} \text { Subject Matter } r_{j i}+ \\
& \text { Effects }+\varepsilon_{i} \\
& \sum \beta_{k i} \text { Opinion Controls } k_{k i}+\sum \beta_{\text {lis }} \text { State Controls }{ }_{i i}+\text { Year }
\end{aligned}
$$

Model 1 of Table 6 reports our results.

Table 6. Professional Arbitrator Regressions

\begin{tabular}{lcc}
\hline & $(1)$ & $(2)$ \\
\hline Professional Arbitrator Chair & 0.349 & -0.863 \\
& $(0.64)$ & $(-0.55)$ \\
Professional Arbitrator Panel & $-1.194^{*}$ & -1.487 \\
& $(-2.05)$ & $(-0.89)$ \\
Claimant Attorney & & 0.731 \\
& & $(0.69)$ \\
Respondent Attorney & & $-2.296^{*}$ \\
& & $(-2.48)$ \\
Professional Arbitrator Chair & & \\
* Claimant Attorney & & 1.541 \\
& & $(0.93)$ \\
Professional Arbitrator Panel & & \\
$*$ Claimant Attorney & & 0.413 \\
& & $(0.23)$ \\
Constant & $-2.382^{+}$ & -0.930 \\
& $(-1.84)$ & $(-0.50)$ \\
\hline$N$ Adj. $R^{2}$ & 239 & 239 \\
Subject Matter Controls & 0.298 & 0.322 \\
Opinion Controls & Yes & Yes \\
State Controls & Yes & Yes \\
\hline
\end{tabular}


Note. Dependent variable for OLS regressions is the log odds of the compensation ratio. Variable definitions are in the Appendix. T-statistics are in parentheses. F-test for Professional Arbitrator Chair + Professional Arbitrator Chair $*$ Claimant Attorney $=0.2439$. F-test for Professional Arbitrator Panel + Professional Arbitrator Panel $*$ Claimant Attorney $=0.0890$

+ Coefficient significant at the $10 \%$ level or less.

${ }^{*}$ Coefficient significant at the $5 \%$ level or less.

${ }^{*}$ Coefficient significant at less than the $1 \%$ level.

The coefficient for Professional Arbitrator Chair is positive, but insignificant. Recall that the parties generally must agree on this position. The coefficient for Professional Arbitrator Panel, however, is negative and significant at the 5\% level. These results suggest that professional arbitrators are inclined to make smaller awards, but only those who are serving as the second public arbitrator, not the chair. These differing results based on the position of the professional arbitrator suggest that this potential conflict of interest is a subtler one. How does the effect interact with the presence of an attorney for the claimant?

To assess this possibility, we re-estimate the model above adding variables for Claimant Attorney, Respondent Attorney, as well as interaction variables for Claimant Attorney and the two Professional Arbitrator variables. We present the results of this regression in Table 6, Model 2. The coefficient for Professional Arbitrator Panel is negative in this model and larger in magnitude, albeit insignificant, which we attribute to the relatively small number of observations in this category. The coefficient for the sum of Professional Arbitrator Panel and Professional Arbitrator Panel*Claimant Attorney is also negative and marginally significant (F-test significant at the $10 \%$ confidence level). This suggests that attorneys do not completely ameliorate the potential conflict of interest created by an arbitrator's potential desire to trim awards to encourage future selection. We conjecture two possible explanations: (1) bias of this sort is sufficiently subtle that even lawyers are not sensitive to it; or (2) the constraints imposed on party selection limit the ability of claimants and their counsel to reject arbitrators on this basis.

\section{E. Retired Arbitrators}

Retired arbitrators may face similar incentives as professional arbitrators. To the extent that an arbitrator is retired, he may face fewer demands on his time. The arbitrator's honorarium, albeit modest, may be more significant to an arbitrator who is retired. As a result, retired arbitrators, like professional 
arbitrators, may be motivated to make lower awards to enhance their future prospects of selection by broker-dealers (Hypothesis 3). To assess the effect of retired arbitrators on the level of awards, we create an indicator variable set equal to one if the arbitrator was retired at the time of the arbitration or over the age of 65 , and zero otherwise. Of course, some of the arbitrators in our sample continued to work full time after the age of 65 , but many did not, even if they had not retired completely. Arbitrators who were only working part time presumably had time available to take on more arbitration work. Insofar as our coding treats some arbitrators who are working full time as retired, it should bias against any significant finding.

Table 7. Retired Arbitrators

\begin{tabular}{ccc}
\hline & $\mathrm{N}$ & $\begin{array}{c}\text { Fraction } \\
\text { Retired }\end{array}$ \\
\hline Chair & 266 & 0.316 \\
Panel & 266 & 0.511 \\
\hline
\end{tabular}

Retired and older arbitrators make up a significant portion of the public arbitrators in our sample. Retired chairs make up nearly a third of the sample and over half of the arbitrators occupying the second public arbitrator position.

To assess the effect of arbitrators on awards, we estimate the following equation for each award using ordinary least squares and robust standard errors:

$$
\begin{aligned}
& \text { Compensation Ratio }=a+\beta_{1 i} \text { Retired_Chair }_{i}+\beta_{2 i} \text { Retired_Panel }_{i}+ \\
& \sum \beta_{j i} \text { Subject Matter }_{j i}+\sum \beta_{k i} \text { Opinion Controlski }+\sum \beta_{l i} \text { State } \\
& \text { Controlssi }+ \text { Year Effects }+\varepsilon_{i}
\end{aligned}
$$

We present the results in Table 8 . 
Table 8. Retired Arbitrator Regressions

\begin{tabular}{|c|c|c|}
\hline & (1) & (2) \\
\hline Retired Chair & $\begin{array}{l}-0.983^{*} \\
(-1.97)\end{array}$ & $\begin{array}{l}0.139 \\
(0.10)\end{array}$ \\
\hline Retired Panel & $\begin{array}{l}0.456 \\
(0.98)\end{array}$ & $\begin{array}{l}0.231 \\
(0.19)\end{array}$ \\
\hline Claimant Attorney & & $\begin{array}{l}1.680 \\
(1.60)\end{array}$ \\
\hline Respondent Attorney & & $\begin{array}{l}-1.563^{+} \\
(-1.69)\end{array}$ \\
\hline $\begin{array}{l}\text { Retired Chair } \\
* \text { Claimant Attorney }\end{array}$ & & $\begin{array}{l}-1.244 \\
(-0.87)\end{array}$ \\
\hline $\begin{array}{l}\text { Retired Panel } \\
* \text { Claimant Attorney }\end{array}$ & & $\begin{array}{l}0.277 \\
(0.21)\end{array}$ \\
\hline Constant & $\begin{array}{l}-2.820^{*} \\
(-2.45) \\
\end{array}$ & $\begin{array}{l}-2.770 \\
(-1.60) \\
\end{array}$ \\
\hline$N$ & 266 & 266 \\
\hline Adj. $R^{2}$ & 0.293 & 0.304 \\
\hline Subject Matter Controls & Yes & Yes \\
\hline Opinion Controls & Yes & Yes \\
\hline State Controls & Yes & Yes \\
\hline
\end{tabular}

Note. Dependent variable for OLS regressions is the log odds of the compensation ratio. Variable definitions are in the Appendix. T-statistics are in parentheses. F-test for Retired Chair + Retired Chair* Claimant Attorney $=$ 0.0398. F-test for Retired Panel + Retired Panel ${ }^{*}$ Claimant Attomey $=0.3126$.

+ Coefficient significant at the $10 \%$ level or less.

${ }^{*}$ Coefficient significant at the $5 \%$ level or less.

${ }^{* *}$ Coefficient significant at less than the $1 \%$ level.

For retired arbitrators, the chair position appears to be relevant. The coefficient for Retired Arbitrator Chair is negative and significant at the 5\% level, while the coefficient for Retired Arbitrator Panel is positive, albeit 
insignificant. Examining the interaction between retired arbitrators and the presence of a claimant attorney in Model 2, the coefficient for Retired Arbitrator Chair is positive in this specification, albeit insignificant, suggesting that claimants who are not represented by counsel do not face any disadvantage when there is a retired chair. The coefficient for sum of Retired Arbitrator Chair and the Retired Arbitrator Chair*Claimant Attorney interaction variable is negative and significant at the $5 \%$ level. As with professional arbitrators, this suggests that attorneys do not completely ameliorate the potential conflict of interest created by a retired arbitrator's potential desire to trim awards to encourage future selection. Our findings suggest that the incentives of professional and retired arbitrators represent a more subtle type of bias that may fly under the radar screen in the party selection process, even with the aid of counsel.

\section{F. Regulatory Experience}

Our next set of tests looks at the effect of an arbitrator's experience as a regulator on their awards. To assess the possibility that experience as a regulator will incline an arbitrator to give more credence to claims of brokerdealer misconduct (Hypothesis 4), we create an indicator variable equal to one if the arbitrator has experience as a federal or state prosecutor, a federal or state securities regulator, or a prior affiliation with a self-regulatory organization, and zero otherwise.

In our earlier tests, we focused only on public arbitrators. For this set of tests, we expand our scrutiny to include the industry arbitrator. We postulate that industry arbitrators with a regulatory background may have a lower tolerance for "bad apples" within the industry because misconduct by an individual broker may undermine investor confidence in the industry generally. Table 9 shows the incidence of experience as a regulator among our three groups of arbitrators. 
Table 9. Regulatory Experience for Public and Industry Arbitrators

\begin{tabular}{lcc}
\hline & $\mathrm{N}$ & $\begin{array}{c}\text { Fraction } \\
\text { Regulators }\end{array}$ \\
\hline Chair & 266 & 0.147 \\
Panel & 253 & 0.083 \\
Industry & 239 & 0.109 \\
\hline
\end{tabular}

Regulatory experience is relatively common among the arbitrators in our sample, especially for industry arbitrators. Among the chairs, $14.7 \%$ had regulatory experience, while $8.3 \%$ of the other public arbitrators had such experience. For industry arbitrators, $10.9 \%$ had prior regulatory experience.

To test the effect of regulatory experience among arbitrators on the level of awards, we estimate the following equation for each award using ordinary least squares and robust standard errors:

$$
\begin{aligned}
& \text { Compensation Ratio }{ }_{i}=a+\beta_{1} \text { Regulator_Cbair }_{i}+\beta_{2 i} \text { Regulator_Panel }_{i}+ \\
& \sum \beta_{j i} \text { Subject Matter }_{j i}+\sum \beta_{k i} \text { Opinion Controls }{ }_{k i}+\sum \beta_{\text {lis }} \text { State Controls }_{k i} \\
& + \text { Year Effects }+\varepsilon_{i}
\end{aligned}
$$

We present the results in Table 10. 
Table 10. Regulatory Experience Regressions

\begin{tabular}{|c|c|c|c|c|}
\hline & (1) & (2) & (3) & (4) \\
\hline Regulator Chair & $\begin{array}{l}0.875 \\
(1.15)\end{array}$ & $\begin{array}{l}-0.251 \\
(-0.12)\end{array}$ & & \\
\hline Regulator Panel & $\begin{array}{c}2.549^{* *} \\
(3.23)\end{array}$ & $\begin{array}{l}3.156 \\
(1.21)\end{array}$ & & \\
\hline Regulator Industry & & & $\begin{array}{l}-0.037 \\
(-0.05)\end{array}$ & $\begin{array}{l}-1.122 \\
(-0.81)\end{array}$ \\
\hline Claimant Attorney & & $\begin{array}{l}1.065 \\
(1.35)\end{array}$ & & $\begin{array}{l}0.918 \\
(0.98)\end{array}$ \\
\hline Respondent Attorney & & $\begin{array}{l}-1.816 \\
(-1.55)\end{array}$ & & $\begin{array}{l}-0.768 \\
(-0.81)\end{array}$ \\
\hline $\begin{array}{l}\text { Regulator Chair } \\
* \text { Respondent } \\
\text { Attorney }\end{array}$ & & $\begin{array}{l}1.388 \\
(0.64)\end{array}$ & & \\
\hline $\begin{array}{l}\text { Regulator Panel } \\
* \text { Respondent } \\
\text { Attorney }\end{array}$ & & $\begin{array}{l}-0.853 \\
(-0.31)\end{array}$ & & \\
\hline $\begin{array}{l}\text { Regular Industry } \\
* \text { Claimant Attorney }\end{array}$ & & & & $\begin{array}{l}1.609 \\
(0.92)\end{array}$ \\
\hline Constant & $\begin{array}{l}-1.684 \\
(-1.27) \\
\end{array}$ & $\begin{array}{l}-0.930 \\
(-0.44) \\
\end{array}$ & $\begin{array}{l}-3.510^{* *} \\
(-2.95) \\
\end{array}$ & $\begin{array}{l}-3.644 \\
(-2.16) \\
\end{array}$ \\
\hline$N$ & 190 & 190 & 239 & 239 \\
\hline Adj. $R^{2}$ & 0.337 & 0.342 & 0.219 & 0.222 \\
\hline $\begin{array}{l}\text { Subject Matter } \\
\text { Controls }\end{array}$ & Yes & Yes & Yes & Yes \\
\hline Opinion Controls & Yes & Yes & Yes & Yes \\
\hline State Controls & Yes & Yes & Yes & Yes \\
\hline
\end{tabular}


Note. Dependent variable for OLS regressions is the log odds of the compensation ratio. Variable definitions are in the Appendix.T-statistics are in parentheses. From Model 2: F-test for Regulator Chair + Regulator Chair * Respondent Attorney $=0.1699$; F-test for Regulator Panel + Regulator Panel $*$ Respondent Attorney $=0.0047$. From Model 4: F-test for Regulator Industry + Regulator Industry $*$ Claimant Attorney $=0.6268$.

+ Coefficient significant at the $10 \%$ level or less.

${ }^{*}$ Coefficient significant at the $5 \%$ level or less.

** Coefficient significant at less than the $1 \%$ level.

Consistent with Hypothesis 4, we find in Model 1 that the coefficients for Regulator Chair and Regulator Panel are both positive. Only the latter is significant, however, at the $1 \%$ level.

In our prior analyses, we assessed the interaction of the presence of an attorney for the claimant with the arbitrator background characteristic of interest. For this set of regressions, however, our hypothesis is that regulatory experience will lead arbitrators to be harder on respondents. Accordingly, we want to see if the presence of an attorney for the respondent mitigates the tendency of public arbitrators with regulatory experience to give larger awards. ${ }^{110}$ In Model 2 of Table 10 we add variables for Claimant Attorney, Respondent Attorney, and interaction variables for Respondent Attorney and the Regulator Chair and Regulator Panel indicator variables. The coefficients for Regulator Chair and Regulator Chair*Respondent Attorney are insignificant in this model, as is the sum of Regulator Chair and Regulator Chair*Respondent Attorney. Similarly, the coefficients for Regulator Panel and Regulator Panel*Respondent Attomey are insignificant in this model, although the sum of Regulator Panel and Regulator Panel*Respondent Attorney is positive and significantly different from zero. Excluding the positive coefficient on Regulator Panel + Regulator

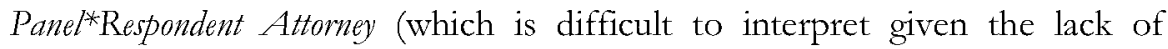
significant coefficients for Regulator Panel and Regulator Panel*Respondent Attorney separately), we do not find substantial evidence that the regulatory experience on the part of a public arbitrator affects the size of the arbitration award.

We also assess the effect of industry arbitrators with regulatory experience, substituting Regulator Industry for the two public arbitrator variables used in the model above. We present the results in Models 3 and 4

110 Importantly, as discussed above, the presence of a plaintiffs' attorney may be a proxy for case quality; the presence of a respondent attorney is less likely to correlate with case quality. 
of Table 10. We see in Model 3 that the coefficient for Regulator Industry is positive, but small in magnitude and insignificant.

Given the small magnitude of the coefficient, we decided to re-estimate the model two different ways. First, we estimated the model with an interaction variable, Regulator Industry*Respondent Attorney, similar to Model 2 in Table 10. Both Regulator Industry and the interaction variable were insignificant in this model, which we have not tabulated. We then re-estimated the model with an interaction variable, Regulator Industry* Claimant Attorney. Our rationale for doing so was that claimant attorneys may play a role in identifying industry arbitrators who were more likely to be generous to their clients. We present the results of this regression in Model 4 of Table 10.

We see that the coefficient for Regulator Industry is negative in this estimation, albeit not significant at conventional levels. The coefficient for the sum of this variable and the variable interacting Regulator Industry with Claimant Attorney is positive, but also insignificant. These findings suggest that prior experience as a regulator among industry arbitrators does not have a significant effect on awards. Although our data does not allow us to ascertain the reason for this finding, it is possible that regulators have a reduced tolerance for weak cases or, alternatively, that industry ties outweigh regulator effects.

\section{G. Compliance Officers}

For our final set of tests, we wanted to see if employment as a compliance officer with a broker-dealer would have an effect on arbitration awards. We posit that compliance officers, like former regulators, may have more familiarity with broker misconduct and therefore may be inclined to make higher awards (Hypothesis 5). Table 11 shows the incidence of experience as a compliance officer in our sample. 
Table 11. Compliance Experience for Public and Industry Arbitrators

\begin{tabular}{lcc}
\hline & $\mathrm{N}$ & $\begin{array}{c}\text { Fraction } \\
\text { Regulators }\end{array}$ \\
\hline Chair & 261 & 0.027 \\
Panel & 250 & 0.040 \\
Industry & 236 & 0.432 \\
\hline
\end{tabular}

The incidence of experience as a compliance officer is relatively low for the public arbitrators in our sample $(2.7 \%$ for chairs and $4.0 \%$ for the public panel member), but quite common among the industry arbitrators $(43.2 \%)$. Because individuals largely self-select into the pool of available arbitrators, it is possible that industry members with compliance experience are more interested in the arbitration process. Without knowing the breakdown for the overall pool of actual and potential industry participants, however, we can only speculate in this regard.

Given the prevalence of compliance officers among the industry arbitrators, we focus our tests on them. We estimate the following equation for each award using ordinary least squares and robust standard errors:

Compensation Ratio $o_{i}=a+\beta_{i i}$ Compliance Industry $_{i}+\sum \beta_{j i}{\text { Subject Matter } \text { M }_{i}+}+$ $\sum \beta_{k i}$ Opinion Controls $k_{k i}+\sum \beta_{k i}$ State Controls $s_{i j}+$ Year Effects $+\varepsilon_{i}$

We present the results in Table 12. 
Table 12. Compliance Experience Industry Arbitrator Regressions

\begin{tabular}{lcc}
\hline & $(1)$ & $(2)$ \\
\hline Compliance Industry & 0.0220 & -2.157 \\
& $(0.04)$ & $(-1.64)$ \\
Claimant Attorney & & -0.067 \\
& & $(-0.06)$ \\
Respondent Attorney & & -0.831 \\
& & $(-0.90)$ \\
Compliance Industry & & $2.473^{+}$ \\
$*$ Claimant Attorney & & $(1.71)$ \\
& & \\
Constant & $-3.701^{* *}$ & -2.760 \\
& $(-3.12)$ & $(-1.45)$ \\
\hline$N \quad 236$ & 236 \\
Adj. $R^{2}$ & 236 & 0.251 \\
Subject Matter & 0.245 & Yes \\
Controls & & \\
Opinion Controls & Yes & Yes \\
State Controls & Yes & Yes \\
\hline
\end{tabular}

Note. Dependent variable for OLS regressions is the log odds of the compensation ratio. Variable definitions are in the Appendix. T-statistics are in parentheses. F-test for Compliance Industry + Compliance Industry * Claimant Attorney $=0.5569$.

+ Coefficient significant at the $10 \%$ level or less.

${ }^{*}$ Coefficient significant at the $5 \%$ level or less.

${ }^{* *}$ Coefficient significant at less than the $1 \%$ level.

The coefficient for the Compliance Industry variable is insignificant in Model 1. In Model 2, we add Claimant Attorney, Respondent Attomey, as well as an interaction variable for Claimant Attorney and the Compliance Industry variable. The coefficient for Compliance Industry, which represents the effect that such arbitrators have on awards when the claimant is not represented by counsel, is negative, with a relatively large magnitude, but it just misses significance at conventional significance levels $(10.3 \%)$. The sum of the 
coefficient of this variable and the interaction variable is positive, but also insignificant. These results are only suggestive that the presence of counsel may make a difference. As with regulators, our findings may be based, in part, on the uncertain effect that a compliance background may have on the manner in which an arbitrator approaches a customer dispute.

\section{IMPLICATIONS}

Our empirical results are consistent with the literature on judicial decision making: Arbitrator characteristics appear to matter for arbitrator outcomes. Specifically, we find that, for the public arbitrators, industry experience is correlated with statistically significant decreases in arbitration awards for claimants who are not represented by counsel. This finding lends support to FINRA's decision to restrict arbitrators with even a modest amount of securities experience from serving as public arbitrators. The finding also lends support to the concern that arbitrators with industry experience tend to disfavor claimants.

We caution, however, that our findings do not necessarily demonstrate arbitrator bias. In the absence of detailed information about the claims, the merits, and the bases for the arbitrators' awards, we have no benchmark against which to evaluate individual awards for "correctness." That is to say, if two panels issued different awards in similar cases, we would have no basis for determining which award was more appropriate.

Our results also provide modest support for theoretical claims that professional and retired arbitrators may have incentives to issue lower awards than other arbitrators and that they, in fact, act in accordance with those incentives. We find that professional arbitrators who do not serve as the panel chair correlate with a statistically significant decrease in awards. Similarly, public chairs who are retired correlate with smaller awards. Our work suggests that arbitrator incentives are important, and that FINRA may want to take such incentives into account in one form or another. Possible options could include modifying the qualification criteria, limiting the number of panels on which a particular arbitrator can sit, or limiting the total amount of income that an individual can earn as a FINRA arbitrator. Of course, any reforms of this sort would have to be weighed against the cost of limiting the available pool of arbitrators.

Looking at prior regulatory experience, we find some evidence that public arbitrators with regulatory experience are inclined toward granting larger awards if they do not serve as the panel chair. Finally, we find marginally 
significant evidence that there is a difference in awards if the industry arbitrator has experience as a compliance officer. These effects, although modest, are in the predicted direction and consistent with the literature identifying a correlation between judicial preferences/ideology and case outcomes.

With respect to the role of counsel, we find similarly mixed effects. Legal representation appears to mitigate but not eliminate the effect of industry experience, such that unrepresented litigants suffer the most from the effect of "industry bias." In contrast, claimants' attorneys do not appear to be sensitive to the incentive effects of being a professional or retired arbitrator. Although we find limited effects from these characteristics, the effects are not eliminated by the presence of counsel, suggesting that characteristics such as retirement or professional arbitrator may create biases that are less visible to counsel than industry experience. From a practical perspective, our findings suggest that counsel may want to focus more on these characteristics in the selection process. By contrast, effects of regulatory and compliance officer experience are greatly affected by legal representation, suggesting that counsel do, in fact, focus on these characteristics.

\section{CONCLUSION}

In an ideal dispute resolution system, the background of an arbitrator would not influence the outcome in arbitration. Each arbitrator would rule impartially, unaffected by his or her prior experiences or future incentives. The reality, however, is that securities arbitration, like other systems of adjudication, cannot achieve that ideal of impartiality. FINRA has recognized the importance of an arbitrator's background in its increasingly stringent qualification requirements. This paper sheds empirical light on whether those changes are likely to affect case outcomes.

We conclude that, although our results are mixed, arbitrator characteristics do affect case outcomes. Specifically, we find that experience in the securities industry, the characteristic at the core of FINRA's revisions to the definition of a public arbitrator, correlates with significantly smaller awards in cases in which the customer is not represented by counsel. Our findings suggest that FINRA may have been justified in imposing increasingly stringent limitations on the category of public arbitrators, and that disclosure alone was insufficient to protect customers from arbitrator bias. More speculatively, this finding suggests that claimants may do better by opting for panels of all public arbitrators. 
With respect to other categories, our findings lend modest support for researchers who theorize that more general characteristics of arbitrators and their backgrounds are also important. Specifically our findings warn that attorneys may be paying insufficient attention to other important arbitrator characteristics.

At the same time, our research suggests a critical role for the attorney in FINRA arbitrations and suggests that unrepresented parties are particularly vulnerable to the risk of arbitrator bias. The party selection process - which in theory empowers both claimants and respondents - may create particular disadvantages for parties who are not represented by counsel.

Supporters of arbitration often highlight its streamlined proceedings and low costs compared to litigation as an advantage for small claimants. ${ }^{11}$ Our findings suggest that, even with streamlined procedures, claimants who lack attorneys may face an uphill battle. Moreover, our findings suggest that the effectiveness of party selection depends in part on access to counsel experienced in the selection procedure. At the same time, however, our findings suggest that counsel may not be fully effective in screening for subtler forms of bias, such as an arbitrator's desire to be selected in future cases.

111 See Barbara Black, How to Improve Retail Investor Protection After the Dodd-Frank. Wall Street Reform and Consumer Protection Act, 13 U. PA. J. Bus. L. 59, 103 (2010) (warning that eliminating mandatory arbitration of customer disputes is likely to have a negative impact on retail investors). 


\section{APPENDIX: VARIABLE DEFINITIONS}

\begin{tabular}{cl} 
Variable & \multicolumn{1}{c}{ Definition } \\
\hline Compensation Ratio & $\begin{array}{l}\text { The total amount of compensation award divided } \\
\text { by the claimed compensation amount. }\end{array}$
\end{tabular}

\section{Subject Matter Controls}

Suitability

Indicator variable equal to 1 if the arbitration involved a suitability claim, including claims involving "know your customer," NYSE Rule 405, and NASD Rule 2310 issues, and 0 otherwise.

Churning

Indicator variable equal to 1 if the arbitration involved a churning, excessive trading, or excessive commission claim and 0 otherwise.

Unauthorized Trades

Indicator variable equal to 1 if the arbitration involved an unauthorized trading claim and 0 otherwise.

Failure to Execute

Indicator variable equal to 1 if the arbitration involved a claim that the broker or brokerage firm failed to execute a transaction, failed to monitor an account properly, improperly executed a transaction, or engaged in activities that resulted in errors in a customer account and 0 otherwise.

Misrepresentation Indicator variable equal to 1 if the arbitration involved misrepresentation, fraud, failure to disclose, Rule 10b-5, common law fraud, or deceptive sales tactic claim and 0 otherwise.

Conversion

Indicator variable equal to 1 if the arbitration involved a theft, conversion, unauthorized withdrawals, or self-dealing claim and 0 otherwise. 
9:43 (2014)

Reported Settlement

Unreported Partial

Settlement

\section{Opinion Controls}

Claimed Compensation

Inexperienced

Top Accused Brokerage

Respondent Failed to Appear

Claimed Punitive

Damages

Claimed CRD

Expungement

Number of Hearings

Opinion Length
Arbitrator Background

89

Indicator variable equal to 1 if the arbitration resulted in a full or partial settlement and the settlement amount was reported and 0 otherwise.

Indicator variable equal to 1 if the arbitration resulted in a partial settlement and the settlement amount was not reported (but the award for the non-settling respondents was reported) and 0 otherwise.

Amount of claimed compensation in dollars by the arbitration claimants.

Indicator variable equal to 1 if the award is from the first year the arbitrator appears in the dataset and 0 otherwise.

Indicator Variable equal to 1 if any of the respondents was one of the top 10 brokerage firms of 1998.

Indicator variable equal to 1 if the any of the respondents failed to appear at the arbitration hearing and 0 otherwise.

Indicator variable equal to 1 if punitive damages were imposed on any of the respondents in the arbitration award and 0 otherwise.

Indicator variable equal to 1 if the CRD records of any of the respondent-brokers was expunged and 0 otherwise.

Number of hearings for the arbitration.

Number of pages in the award opinion. 


\section{Arbitrator Background}

Securities Experience Indicator variable equal to 1 if the arbitrator's primary career experience was in the securities industry or the arbitrator had worked for a securities firm within the last 5 years, and 0 otherwise.

Professional Arbitrator

Indicator variable equal to 1 if the arbitrator primarily works as arbitrator or is self-employed and 0 otherwise.

Retired

Indicator variable equal to 1 if the arbitrator is retired or over age 65 at the time of arbitration and 0 otherwise.

Regulator

Indicator variable equal to 1 if the arbitrator has experience as a federal or state prosecutor, federal or state securities regulator, or with a selfregulatory organization, and 0 otherwise.

Compliance

Indicator variable equal to 1 if the arbitrator has experience as a compliance officer with a brokerdealer, and 0 otherwise. 